Prepared in cooperation with the National Park Service

\title{
Historical Rock Falls in Yosemite National Park, California (1857-2011)
}

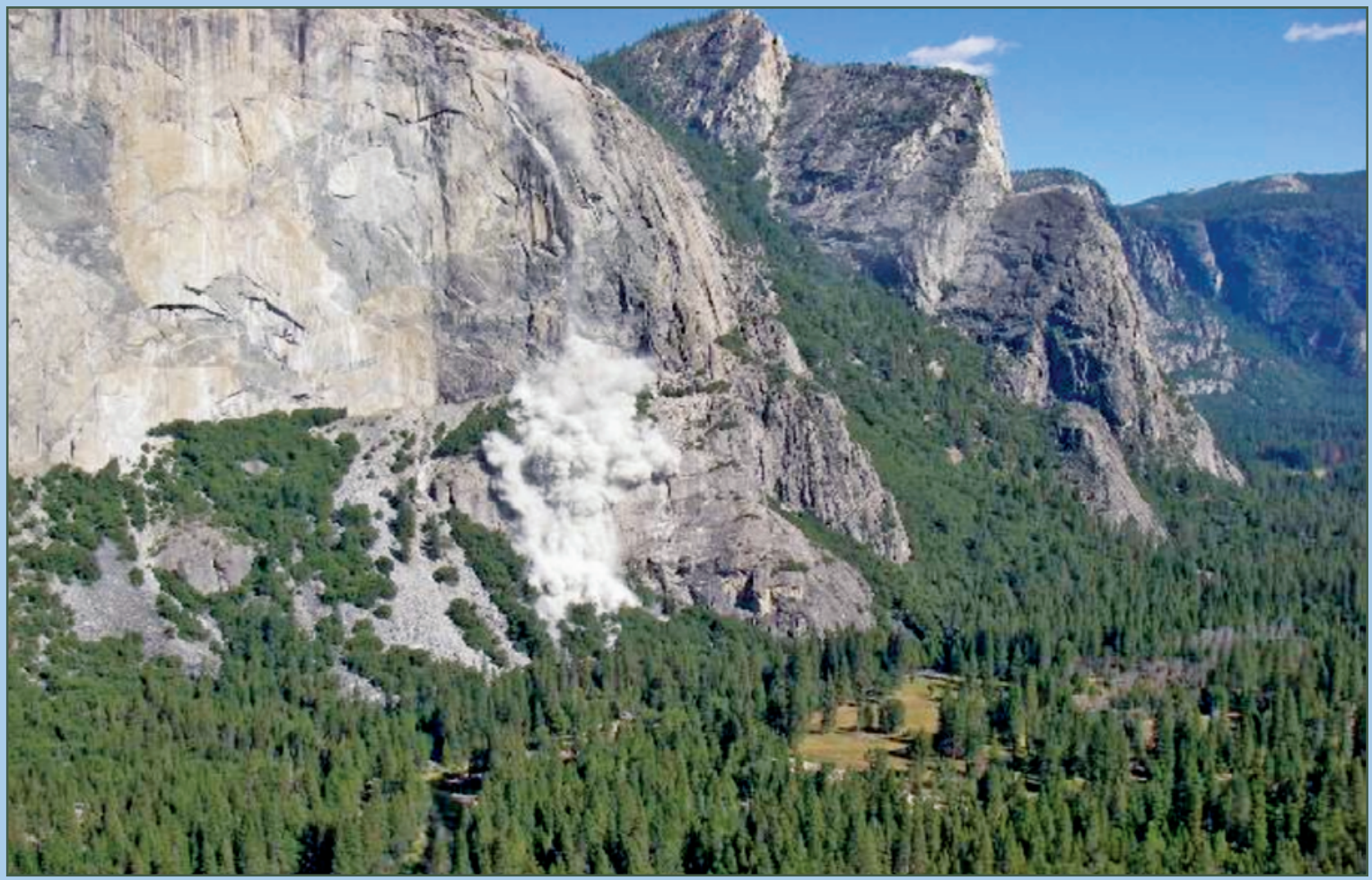

Data Series 746 
Photograph of the October 11, 2010, rock fall from the southeastern face of El Capitan. Photograph by Luke Lydiard, used with permission. 


\section{Historical Rock Falls in Yosemite National Park, California (1857-2011)}

By Greg M. Stock, Brian D. Collins, David J. Santaniello, Valerie L. Zimmer, Gerald F. Wieczorek, and James B. Snyder

Prepared in cooperation with the National Park Service

Data Series 746 


\title{
U.S. Department of the Interior SALLY JEWELL, Secretary
}

\section{U.S. Geological Survey Suzette M. Kimball, Acting Director}

\author{
U.S. Geological Survey, Reston, Virginia: 2013
}

For product and ordering information: World Wide Web: http://www.usgs.gov/pubprod Telephone: 1-888-ASK-USGS

For more information on the USGS - the Federal source for science about the Earth, its natural and living resources, natural hazards, and the environment: World Wide Web: http://www.usgs.gov

Telephone: 1-888-ASK-USGS

Any use of trade, firm, or product names is for descriptive purposes only and does not imply endorsement by the U.S. Government.

Although this information product, for the most part, is in the public domain, it also may contain copyrighted materials as noted in the text. Permission to reproduce copyrighted items must be secured from the copyright owner.

Suggested citation:

Stock, G.M., Collins, B.D., Santaniello, D.J., Zimmer, V.L., Wieczorek, G.F., and Snyder, J.B., 2013, Historical rock falls in Yosemite National Park, California (1857-2011): U.S. Geological Survey Data Series 746, 17 p. and data files, http://pubs.usgs.gov/ds/746/. 


\section{Contents}

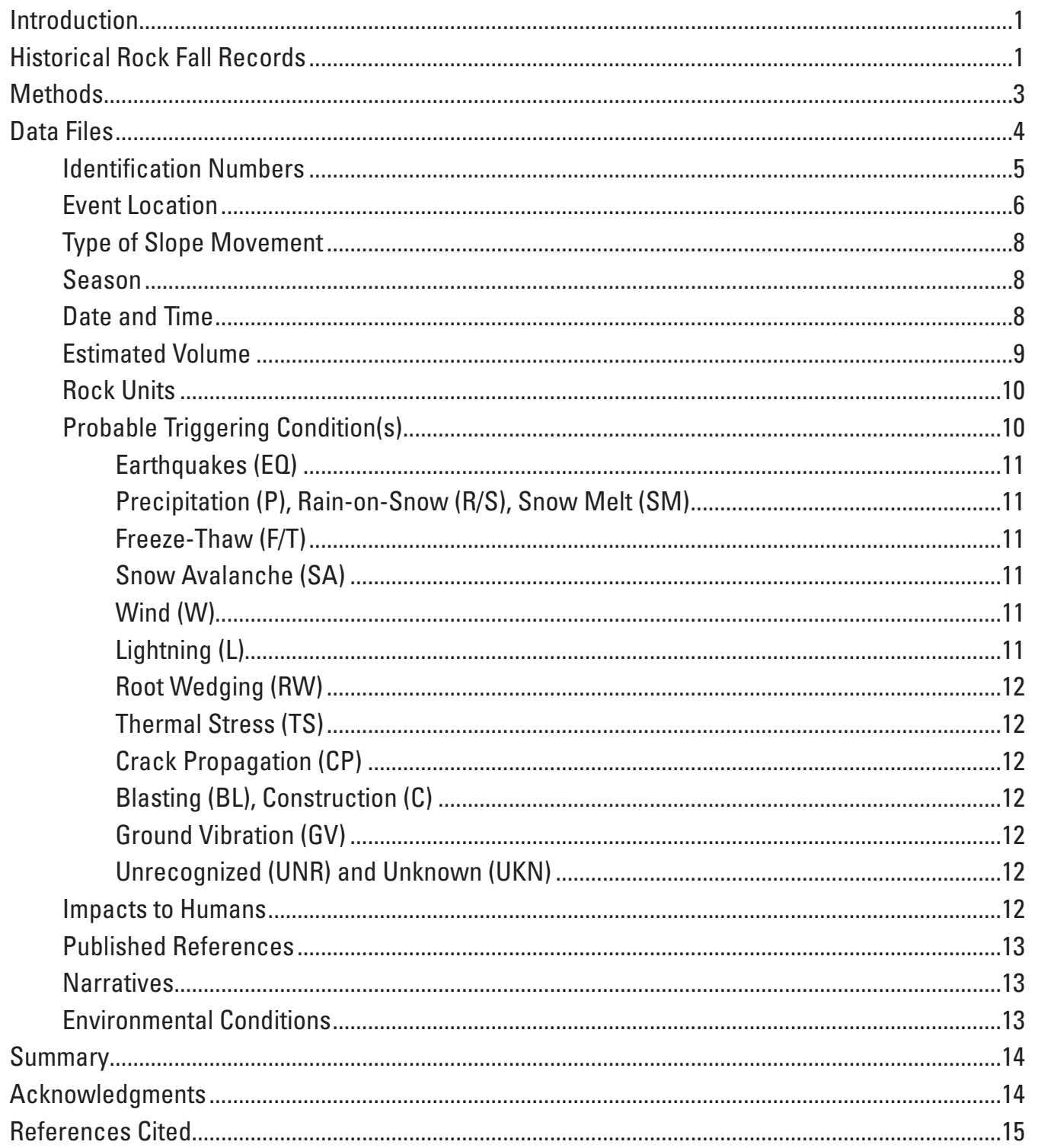

\section{Figures}

1. Shaded relief map of Yosemite National Park showing general locations referred to in this report.

2. Photograph of Yosemite Valley looking east, showing the steep granitic cliffs that flank the valley

3. Shaded relief map of Yosemite Valley derived from 1-m airborne lidar data showing general locations and additional location information where documented rock falls occurred ..4

4. Example format of "Master" sheet from the rock fall database ..................................................5

5. Example format of "Environmental Conditions" sheet from the rock fall database ...................5 
6. Example format of "References" sheet from the rock fall database .........................................6

7. Example format of the rock fall database narrative document ..................................................14

\section{Tables}

1. Geographic names and labels of select locations in Yosemite National Park .7

2. Relative size categories of rock falls in Yosemite National Park............................................10

3. Rock units comprising rock falls in Yosemite National Park....................................................10

\section{Datum Information}

Horizontal coordinate information is referenced to the North American Datum of 1983 (NAD 83) and projected to Universal Transverse Mercator (UTM) Zone 11S coordinates in metric units.

Vertical coordinate information is referenced in metric units to the North American Vertical Datum of 1988 (NAVD 88). Elevation, as used in this report, refers to distance above the vertical datum. 


\title{
Historical Rock Falls in Yosemite National Park, California (1857-2011)
}

\author{
By Greg M. Stock', Brian D. Collins², David J. Santaniello', Valerie L. Zimmer', Gerald F. Wieczorek², and \\ James B. Snyder ${ }^{4}$
}

\section{Introduction}

Inventories of rock falls and other types of landslides are valuable tools for improving understanding of these events. For example, detailed information on rock falls is critical for identifying mechanisms that trigger rock falls, for quantifying the susceptibility of different cliffs to rock falls, and for developing magnitude-frequency relations (for example, Wieczorek and Jäger, 1996; Dussauge-Peisser and others, 2002; Chau and others, 2003; Dussauge and others, 2003; Guzzetti and others, 2003; Malamud and others, 2004; Brunnetti and others, 2009; Tatard and others, 2010; Hergarten 2012). Further, inventories can assist in quantifying the relative hazard and risk posed by these events over both short and long time scales (for example, Hungr and others, 1999; Guzzetti and others, 2003; Wieczorek and Snyder, 2009). This report describes the accompanying rock fall inventory database for Yosemite National Park, California (fig.1). The inventory database documents 925 events spanning the period 1857-2011.

Rock falls, rock slides, and other forms of slope movement represent a serious natural hazard in Yosemite National Park. Rock-fall hazard and risk are particularly relevant in Yosemite Valley, where glacially steepened granitic cliffs approach $1 \mathrm{~km}$ in height (fig. 2) and where the majority of the approximately 4 million yearly visitors to the park congregate. In addition to damaging roads, trails, and other facilities, rock falls and other slope movement events have killed 15 people and injured at least 85 people in the park since the first documented rock fall in 1857.

Herein we use the term "rock fall" as a generic, collective term for all slope-movement processes (that is, landslides) in Yosemite, including rock falls, rock slides, debris slides, debris flows, debris slumps, and earth slumps, as described by the slope movement classification system of Varnes (1978). Although the database contains examples of all types of slope movements, rock falls are the dominant mode due to the very steep and relatively unfractured granitic cliffs in many areas of Yosemite National Park, particularly in Yosemite Valley (fig. 3). Most other documented rock falls in the park occurred in near proximity to Yosemite Valley, primarily in adjacent

\footnotetext{
${ }^{1}$ National Park Service, Yosemite National Park, El Portal, California

${ }^{2}$ U.S. Geological Survey, Menlo Park, California

${ }^{3}$ U.S. Geological Survey, Reston, Virginia (retired)

${ }^{4}$ National Park Service, Yosemite National Park, El Portal, California (retired)
}

Tenaya Canyon and along the El Portal and Big Oak Flat Roads in the Merced River gorge (fig. 1).

This report begins with a brief summary of previous and current work on documenting rock falls in Yosemite National Park. It then describes each of the organizational categories in the inventory database, including event location, type of slope movement, date, volume, relative size, probable trigger, impact to humans, narrative description, references, and environmental conditions. The inventory database itself is contained in a Microsoft Excel spreadsheet (Yosemite_rock_ fall_database_1857-2011.xlsx). Narrative descriptions of events are contained in the database, but are also provided in a more readable Adobe portable document format (pdf) file (Yosemite_rock_fall_database_narratives_1857-2011.pdf).

\section{Historical Rock Fall Records}

Rock falls have occurred in Yosemite National Park since deglaciation of the region exposed most of the cliffs between about 15,000 and 19,000 years ago (Matthes, 1930; Huber, 1987; Wieczorek and Jäger, 1996). Although native people inhabited Yosemite Valley for millennia, there are no formally recorded rock falls during this period because of a lack of a written history. Following the modern discovery of Yosemite Valley in 1851, larger rock falls were mentioned in the writings of many visitors, including Josiah Whitney (State Geologist of California), John Muir (noted naturalist) and Joseph LeConte (professor of geology at the University of California). More systematic documentation of both small and large rock falls affecting facilities began after 1916 and was recorded in the monthly National Park Service (NPS) Superintendent's Reports, because repairs were necessary to maintain damaged trails and roads. Following a multiplefatality rock fall onto the Yosemite Falls Trail in 1980 (Snyder, 1981), the U.S. Geological Survey (USGS) assumed a more prominent role in landslide studies in Yosemite, collaborating with the NPS to document rock-fall events in detail (Wieczorek, 1981; Wieczorek and others, 1989). An initial collection of historical landslide information compiled by the NPS became the basis of the first rock-fall inventory (Wieczorek and others, 1992), which was subsequently updated and expanded by Wieczorek and Snyder (2004). The report and inventory database presented here represents a further update to and expansion of these earlier works. 


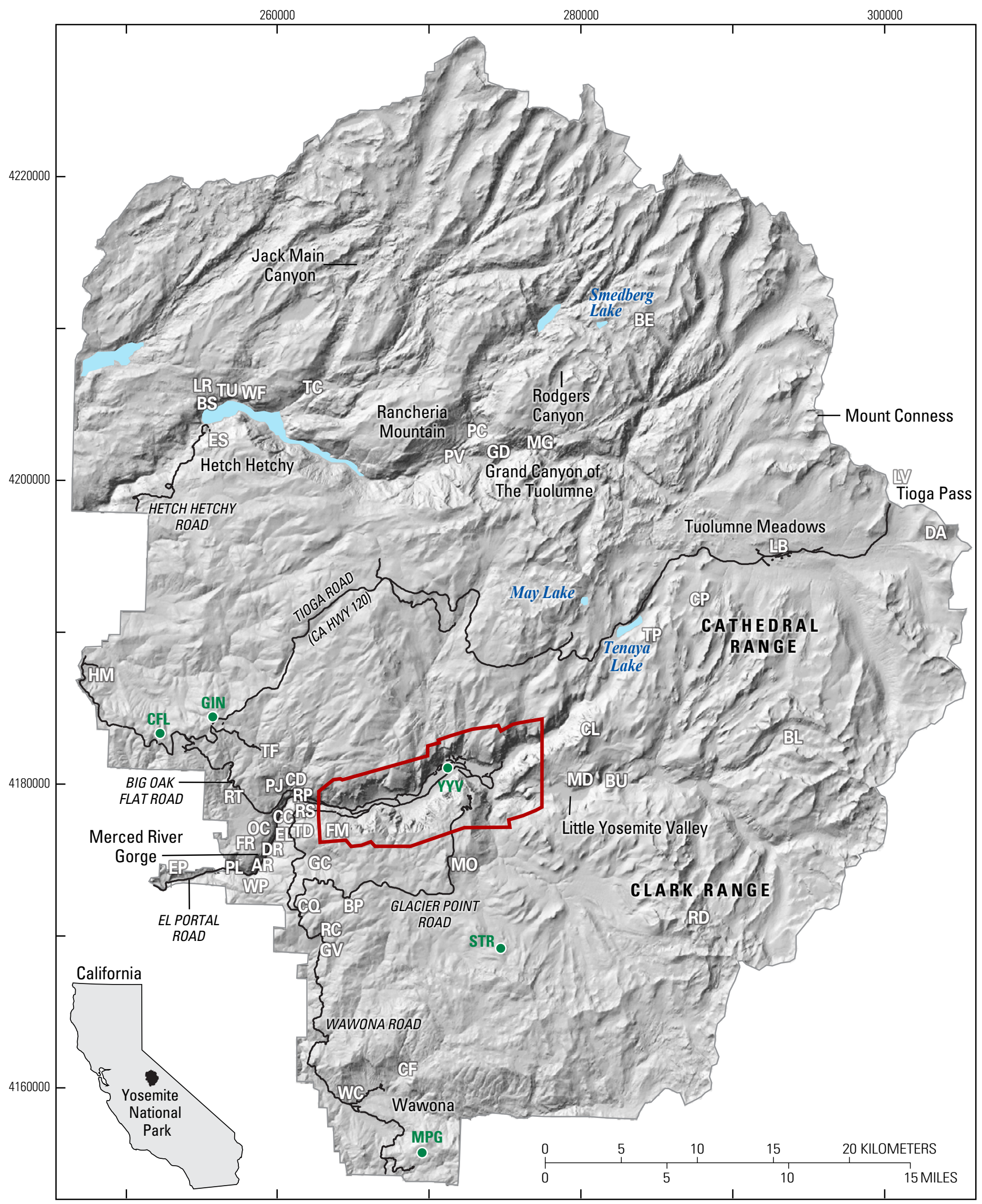

Base map created from 2006 airborne lidar. 


\section{Methods}

The information reported in the inventory database was collected from review of published and unpublished historical accounts, archival records, scientific reports and papers, field studies, collection and interpretation of photographs and remote sensing data, eyewitness observations, and other reports from park visitors, employees, and residents. Since the early 20th century, many complementary investigations and mapping of prehistorical, historical, and recent rock falls and associated hazard and risk have also been conducted in Yosemite (for example, Matthes, 1930; Snyder, 1981, 1986a, 1986b, 1996; Wieczorek and others, 1995; 1998, 1999, 2000, 2008; Wieczorek and Jäger, 1996; Uhrhammer, 1996; Wieczorek and Snyder, 1999; Wieczorek, 2002; Guzzetti and others, 2003; Huber and others, 2007; Wieczorek and others,
2008; Collins and Stock, 2010; Stock and Uhrhammer, 2010; Stock and others, 2011, 2012; Zimmer and others, 2012).

Many of the narrative descriptions provided in this database draw on these works. Additional information about some of the data columns (for example, environmental conditions) are provided in the "Data Files" section of this report.

Many more than the 925 rock falls reported here undoubtedly occurred during the period of record investigated herein (1857-2011), but these events went unnoticed or unreported because of the small size of individual rock falls or the lack of impact to trails, roads, structures or utilities. In addition, some larger, historical rock falls are not included, despite the fact that at least some information on these events is known. During preparation of this and earlier versions of the inventory database, examination of historical photographs identified some rock falls that had never been reported. For

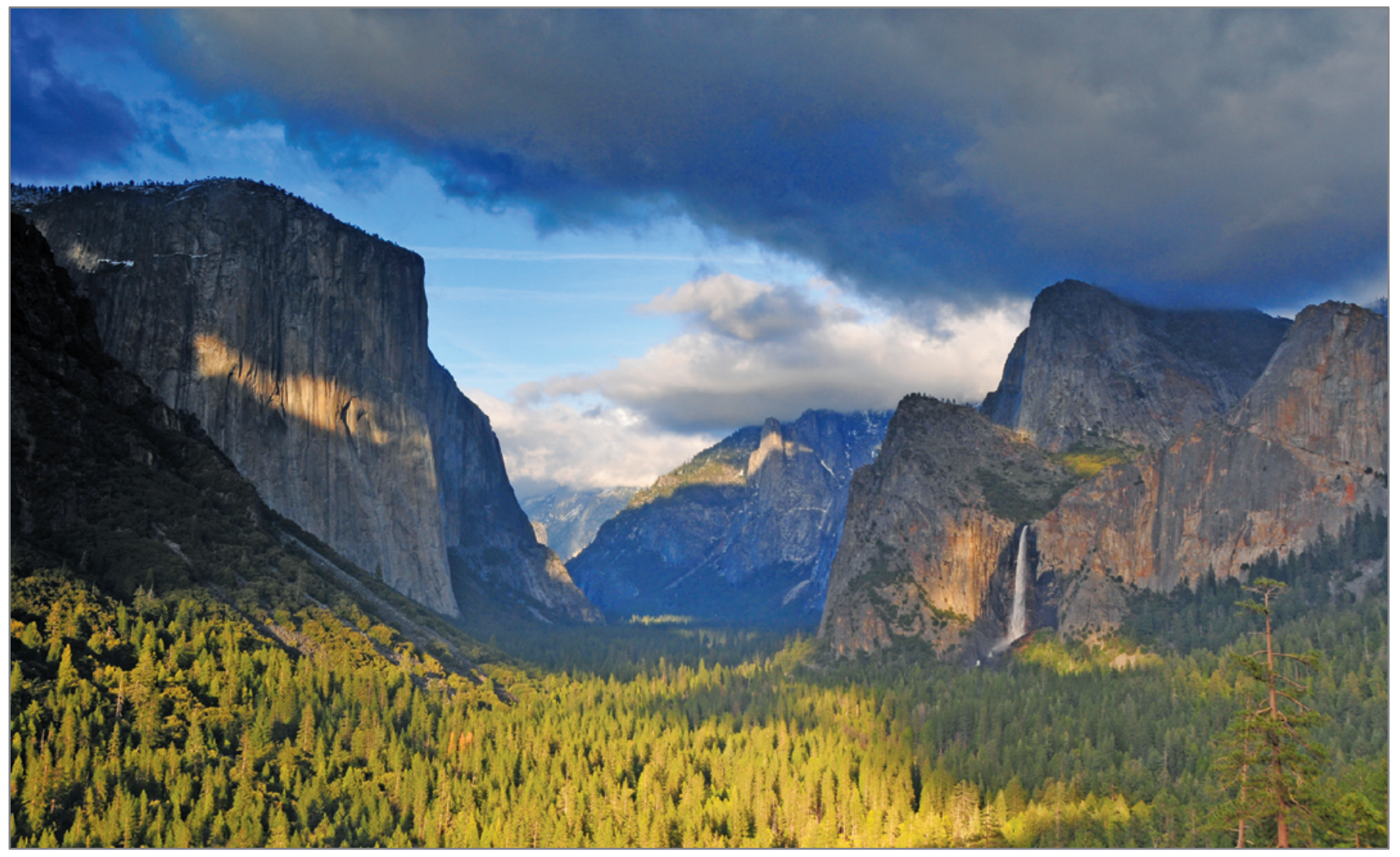

Figure 1. Shaded relief map of Yosemite National Park showing general locations referred to in this report. Additional geographic features referenced in the database are indicated by white two-letter labels (refer to table 1 for key). The two-letter labels represent geographic locations only-they should not be interpreted as marking the precise locations of rock falls. Black lines mark major roadways. Green circles mark meteorological stations used to compile environmental conditions that existed during and prior to rock falls; GIN = Gin Flat, CFL $=$ Crane Flat, YYV $=$ Yosemite Valley, STR $=$ Ostrander, MPG = Mariposa Grove. Red polygon indicates the Yosemite Valley area shown in figure 3.
Figure 2. Photograph of Yosemite Valley looking east, showing the steep granitic cliffs that flank the valley. The cliff of El Capitan on the left side of the photo is approximately $915 \mathrm{~m}$ in height. Bridalveil Fall is in the centerright of the photo. Photo by Christine Loberg, used with permission. 
example, historical photographs of the eastern portion of Glacier Point document the occurrence of unreported rock falls in the 1850s, around 1900, and around 1950. However, the timing of these events can only be widely bracketed by the irregular time interval (years to decades) between available photographs and the limited areas covered by the photos. Because some event attributes can only be assigned if the timing of events is reasonably well known (for example, season, probable trigger), events that could not be located in time within a 5-year period are excluded from this database.

\section{Data Files}

The rock fall inventory data are contained in three separate sheets within the accompanying Excel spreadsheet file and within a pdf document of the narrative descriptions of events. The first Excel sheet (see example in fig. 4) is titled "Master" and contains an unique number assigned to each event (ID), the location, type of slope movement, season, date and time of occurrence, estimated volume, volume range and relative size of event, probable trigger, rock type, impact to humans (fatalities, injuries and infrastructure impacts) if any, citation of any published sources of information pertaining to the event, and a narrative description of the event. The second Excel sheet (see example in fig. 5) is titled "Environmental Conditions" and adds temporally corresponding environmental data, including temperature and precipitation conditions, when it exists, for each rock-fall event. This allows users to independently evaluate the environmental conditions leading up to and during the time of occurrence. Also included in the "Environmental Conditions" sheets are the event ID, location, failure type, and probable trigger. The last sheet, titled "References" (see example in fig. 6), contains a complete list of references corresponding to the database entries in the "Master" sheet.

In addition to updating the earlier database of Wieczorek and Snyder (2004), by reporting an additional 406 rock falls and other slope-movement events, this version also makes

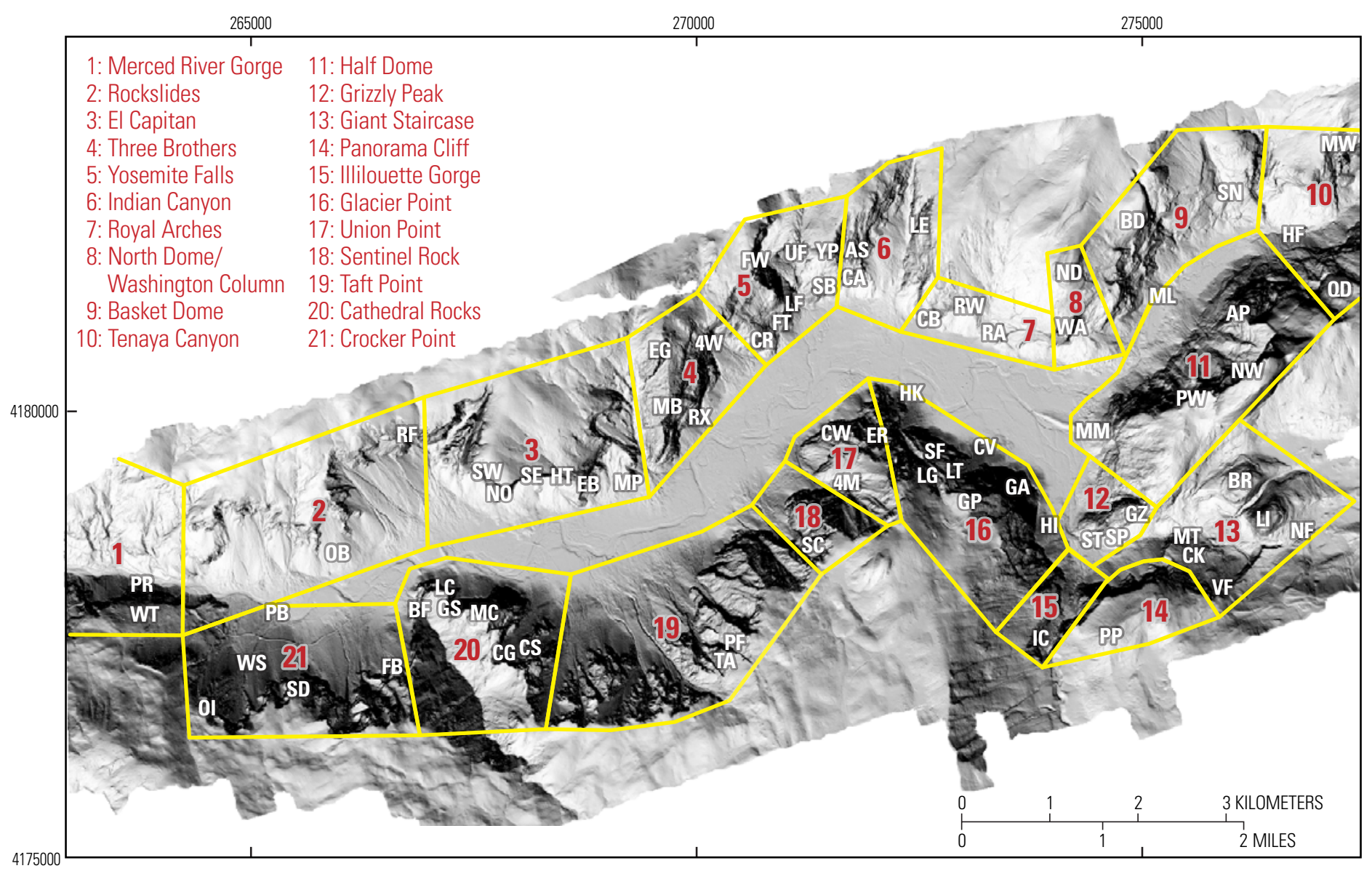

Figure 3. Shaded relief map of Yosemite Valley derived from $1 \mathrm{~m}$ airborne lidar (light detection and ranging) data showing general locations (numbered labels) and additional location information (white two-letter labels—refer to table 1 for location key) where documented rock falls occurred. The 21 delineated areas represent large areas of Yosemite Valley, within which additional information on particular rock fall locations is reported in the database. The two-letter labels represent geographic locations only-they should not be interpreted as marking the precise locations of rock falls. 
several modifications to the digital files of the data. These modifications include adding columns to the database file, a restructuring of column formatting, and a new separate document for the narrative descriptions. This reformatting should provide improved usability of the database and more consistent reporting of event attributes (for example, location, date and time, and volume range). Details of these modifications are provided below as a reference for those users already familiar with previous versions of this database.

\section{Identification Numbers}

Each rock fall or other slope movement in the database has been assigned an unique identification (ID) number that is assigned based on the year (YYYY), month (MM), and day (DD) of the rock fall in a YYYYMMDDXX format where $\mathrm{XX}$ allows for multiple rock falls occurring on the same day. For example, ID 2003122602 refers to the second rock fall that occurred on December 26, 2003. When the exact date is

\begin{tabular}{|c|c|c|c|c|c|c|c|c|c|c|c|c|c|c|c|c|c|}
\hline 4 & A & $\theta$ & c & D & E & $F$ & 0 & H & 1 & J & $\mathrm{k}$ & L & M & $\mathrm{N}$ & 0 & $\mathbf{P}$ & 0 \\
\hline 1 & & Historic & cal Rock & ck Falls in Yosemite Nationa & al Park, Callfornia (1857-2011) & & & & & & & & & & & & \\
\hline 2 & & U.s. Ge & ological & Survey Data Series 746 & & & & & & & & & & & & & \\
\hline 3 & & Greg M. : & Stock, Brie & Kien D. Collns, Devile J. Santanielle & b. Valerie L. Zimmer, Geraid F. Wieczen & reak. Lamess B. Sryder & & & & & & & & & & & \\
\hline 4 & & & & & & & & & & & & & & & & & \\
\hline 5 & & MASTE & R SHE: & & & & & & & & & & & & & & \\
\hline 6 & & & & & & & & & & & & & & Estimated volumes ( $\left(\mathrm{m}^{3}\right.$ & & & \\
\hline 7 & ID 2011 & ID 2004 & 10 1902 & 2 Genoral location & Addational location information & $\begin{array}{l}\text { Figure location } \\
\text { reforence (sect figa. } 1 \\
\text { and 3, teble 1) }\end{array}$ & $\begin{array}{c}\text { Type of } \\
\text { slope } \\
\text { movement }\end{array}$ & Soason & Yoar & Month & Day & $\pi m e(P S T)$ & $\begin{array}{c}\text { Minimum } \\
\text { volume }\end{array}$ & $\begin{array}{c}\text { Medianfost } \\
\text { estimate volume }\end{array}$ & $\begin{array}{c}\text { Maximum } \\
\text { volume }\end{array}$ & Rolative size & Rock unit \\
\hline 8 & 1857000001 & 1 & $2 R$ & Tan Point & Protio Cirt & F3-19, PF & QFF & nia & 1857 & na & $\mathrm{Na}$ & n/a & 50000 & 200000 & 500000 & extromey large & Kos \\
\hline 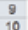 & 18580000001 & 2 & & Yosumino Falls & no & F3.5 & RF & no & 1868 & nia & $\mathrm{ma}$ & no & & 185000 & & extremoly large & KeKec \\
\hline $\begin{array}{l}10 \\
11\end{array}$ & $\begin{array}{l}1865061101 \\
105411301\end{array}$ & ${ }_{4}^{3}$ & $3 R$ & Yosemith Falls & Yosente Folls & $\begin{array}{ll}F 2.5 \\
F 3.8\end{array}$ & $\underset{P F}{R F}$ & Soring & 1860 & 6 & 11 & n/o & 500 & 2000 & 5000 & lengo & Kakec \\
\hline $\begin{array}{l}11 \\
12\end{array}$ & 18564113001 & $\frac{4}{5}$ & $\begin{array}{l}3 R \\
13\end{array}$ & $\begin{array}{l}\text { Sentinel Rock } \\
\text { Cathedral Rooks }\end{array}$ & $\begin{array}{l}\text { Senthel Rock } \\
\text { Cotherital Rocks }\end{array}$ & $83-20$ & $\begin{array}{l}\text { RF } \\
\text { RF }\end{array}$ & Foll & 1864 & 11 & 13 & wote pm & 5000 & 20000 & 500000 & very large & $\mathrm{Ks}$ \\
\hline $\begin{array}{l}12 \\
13\end{array}$ & $\begin{array}{l}18680000010 \\
1870070101\end{array}$ & $\begin{array}{l}5 \\
6\end{array}$ & 13 & Catheral Rocks & Coflitedrat Rocks & F3:2011 & $R F$ & sumper & $\begin{array}{l}1808, \text {, fat } \\
1870\end{array}$ & ${ }^{\mathrm{na}}$ & ${ }_{1.7}$ & nee & 5000 & 20000 & 50000 & very large & Kee \\
\hline 14 & 1870089601 & 7 & $A R$ & Gincier Poins: & Rat Domo & F3-16 & $R F$ & Summer. & $\begin{array}{l}1870 \\
1870\end{array}$ & 8 & $\frac{1-7}{5}$ & extrom & 5000 & 700 & 50000 & mocaum & Kha \\
\hline $\begin{array}{l}14 \\
15\end{array}$ & 1872032601 & 8 & 50 & Union Point & Eogie Rock & $F 3-17, E R$ & $\mathrm{RF}$ & sorng & 1872 & 3 & $\therefore 6$ & (6ary & 5000 & 20000 & $\begin{array}{l}500000 \\
50000\end{array}$ & very largo & Kgp \\
\hline 16 & 1872032602 & 9 & $G R$ & Olent Starcesse & Uberty Cep & F3-13, U & RF & Spring & $\begin{array}{l}1872 \\
1872\end{array}$ & 3 & 26 & 230 & 000 & 36000 & . & $\begin{array}{l}\text { very large } \\
\text { very large }\end{array}$ & kgp \\
\hline $\begin{array}{l}10 \\
17\end{array}$ & 1872032603 & 10 & $7 R$ & Sentinel Rock & Sentinel Rock & F3-18 & RF & $\begin{array}{l}\text { sperno } \\
\text { spring }\end{array}$ & $\begin{array}{l}1872 \\
1872\end{array}$ & ${ }_{3}^{3}$ & 26 & $\begin{array}{l}2300 \\
230\end{array}$ & 500 & $\begin{array}{l}360000 \\
2000\end{array}$ & 5000 & very large & Ks \\
\hline 18 & 1872032604 & 11 & 8 & indian Canyon & Incian Canyon & $F 3.6$ & RF & spreng & 1872 & 3 & 26 & $2: 30$ & 500 & 2000 & 5000 & lange & $\mathrm{ks}$ \\
\hline 19 & 1872032605 & 12 & 9 & Hlovetto Gorge & lobuotio Gorgo & $F 3-15$ & RF & sorng & 1872 & 3 & 26 & $2: 30$ & 500 & 2000 & 5000 & longo & Knd \\
\hline 20 & 1872032605 & 13 & 100 & Union Point & Eogle Rock & $F 3-17, E R$ & RS & soring & 1872 & 3 & 26 & 3.30 & 800 & 2000 & 8000 & lenge & $\mathrm{Kgg}$ \\
\hline 21 & 1873030501 & & & Yosenvile Falls & sunnysice Bench & F3.5. SB & SA & Winter & 1873 & 3 & 5 & n/o & 0.5 & 2 & 5 & very small & Ks Kes \\
\hline 22 & 1873031201 & 14 & $12 R$ & Theee Brothers & Misdle Brother & F3-4, MB & RF & Winter & 1873 & 3 & 12 & n/e & 3000 & 20000 & 50000 & very large & Ks/Kes \\
\hline 23 & 18860000001 & 18 & 15R & indian canyon & increan canyon & F3.6 & RS & Fal & 1885 & na & $\mathrm{na}$ & $n / a$ & 500 & 200 & 9000 & large & at \\
\hline 24 & 1886032101 & 15 & & Merced Rower Gorge & El Portal Rood / Arch Roek & $F 1, A R$ & RF & sorng & 1885 & 3 & 21 & $\mathrm{am}$ & - & 1500 & - & lorge & Kga \\
\hline 25 & 1806041701 & 16 & & Union Point & Union Point & $F 3-17$ & RF & Soring & 1805 & 4 & 17 & N/o & - & 1000 & - & lengo & Koc \\
\hline 26 & 1896041901 & 17 & 148 & Sentine: Rock & Sentinel Rock & F3-18 & RS & spring & 1885 & 4 & 19 & n/e & so & 200 & 500 & medium & $\mathrm{ks}$ \\
\hline 27 & 18880500001 & 29 & 280 & Union Point & Four Mas Tral & F3-17, 4M & RS & spring & 1888-1905 & 5 & n/a & nio & $\therefore$ & 3 & $\therefore$ & very small & Kopikes \\
\hline 28 & 1860050002 & 30 & 270 & Glacler Point & Four Mae Tral & F3-17, 4M & RS & Summer & 1886-1905 & s.9 & $\mathrm{n} / \mathrm{a}$ & nia & 500 & 2000 & 5000 & large & Kgp \\
\hline
\end{tabular}

Figure 4. Example format of "Master" sheet from the rock fall database. Only a small selection of the rock fall events and organizational categories are shown.

\begin{tabular}{|c|c|c|c|c|c|c|c|c|c|c|c|c|c|c|c|c|c|}
\hline 4 & A & 8 & $c$ & $D$ & E & $\mathbf{F}$ & o & $\mathrm{H}$ & 1 & J & K & L & M & N & 0 & P & a \\
\hline 1 & & \multirow{2}{*}{\multicolumn{4}{|c|}{$\begin{array}{l}\text { Historical Rock Falls in Yosemilte National Park, Californla (1857-2011) } \\
\text { U.S. Geological Survey Data Series } 746\end{array}$}} & & & & & & & & & & & & \\
\hline 2 & & & & & & & & & & & & & & & & & \\
\hline 3 & & \multicolumn{2}{|c|}{ 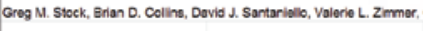 } & arast $F . W$ & loczorek, & Jamoo $\mathrm{B}$ & snycer & & & & & & & & & & \\
\hline 4 & & \multirow{2}{*}{\multicolumn{2}{|c|}{ ENVIRONMENTAL CONDITIONS SHEET }} & & & & & & & & & & & & & & \\
\hline \multirow[t]{2}{*}{5} & & & & & & & & & & & & & & & & & \\
\hline & & & & & & & & \multicolumn{5}{|c|}{$\begin{array}{l}\text { Yosemite Valley rim tomperatures ('C): tomperatures adjustoc for rim } \\
\text { olevation (2377 m), assuming } 0.65-\mathrm{c} / 100 \mathrm{~m} \text { lapso rato }\end{array}$} & \multicolumn{4}{|c|}{ Yosemilte Valley (1219 m elevation) temperature ('C) } \\
\hline 7 & ID 2011 & Oeneral location & Additional location intormation & Year & Month & $\stackrel{D a y}{.}$ & Time (PST) & $\begin{array}{c}\text { Type of } \\
\text { slope } \\
\text { movement: }\end{array}$ & \begin{tabular}{c|} 
Maximum \\
tomporaturo \\
24 hours pritor \\
to ovevent
\end{tabular} & \begin{tabular}{|c|} 
Minimum \\
tomporature \\
24 hours pricer \\
to ovent
\end{tabular} & \begin{tabular}{c|} 
Mean \\
tomperature \\
24 hours prioe \\
to event
\end{tabular} & \begin{tabular}{|c|}
$\begin{array}{c}\text { Temperature } \\
\text { ot the time of } \\
\text { event }\end{array}$ \\
\end{tabular} & \begin{tabular}{|c|}
$\begin{array}{c}\text { Number of } \\
\text { contributing } \\
\text { stations }\end{array}$ \\
\end{tabular} & \begin{tabular}{|c|} 
Maximum \\
tomporature \\
24 hours prior \\
to event
\end{tabular} & \begin{tabular}{|c|} 
Minimum \\
tomporature \\
24 hours prior \\
to overt
\end{tabular} & \begin{tabular}{|c|} 
Moan \\
tomporature \\
24 hours prior \\
to ovent
\end{tabular} & $\begin{array}{l}\text { Temperature } \\
\text { at the time of } \\
\text { event }\end{array}$ \\
\hline 837 & 2011032603 & Hotch Holchy & Wapama Fals & 2011 & 3 & 25 & nia & RF & -1 & -11 & -6 & -6 & 3 & $\frac{1}{8}$ & -3 & 2 & 1 \\
\hline 838 & 2011042001 & Three Ereothers & Misclo Brether & 2011 & 4 & 20 & $16: 10$ & $\mathrm{RF}$ & 5 & -2 & 2 & 2 & 3 & 16 & 7 & $\theta$ & 11 \\
\hline 839 & 2011042002 & Throe Brothers & Mideclo Brother & 2011 & 4 & 20 & $20: 10$ & RF & 4 & -2 & $i$ & -1 & 3 & 13 & 7 & 9 & 7 \\
\hline 890 & 2011050101 & Gacior Point & Happy / Isies & 2011 & 5 & 1 & $18: 30$ & RF & 12 & .2 & 4 & 6 & 2 & 22 & 3 & 11 & 12 \\
\hline 891 & 2011052101 & Cathecral Rocks & Catredral Gully & 2011 & 5 & 21 & $14: 00$ & RF & 13 & 4 & 7 & 12 & 2 & 23 & 9 & 13 & 22 \\
\hline 892 & 2011052701 & Hart Dome & Nerthwest Face & 2011 & 5 & 27 & $16: 41$ & RF & 13 & 1 & 6 & 7 & 2 & 22 & 4 & 11 & 14 \\
\hline 893 & 2011051501 & Hat Dome & Anwoyan Point & 2011 & 6 & 15 & 17:10 & RF & 22 & 12 & 16 & 19 & 2 & 31 & 13 & 21 & 21 \\
\hline 894 & 2011062101 & Corthesral Rocks & Lower Cathecral Rosk & 2011 & 6 & 21 & $9: 30$ & RF & 24 & 12 & 17 & 24 & 2 & 31 & 13 & 21 & 24 \\
\hline 898 & 2011062601 & Indian Canyen & Lohamito Falts & 2011 & 6 & 26 & $15: 32$ & RF & 21 & 9 & 14 & 20 & 2 & 31 & 11 & 18 & 28 \\
\hline 896 & 2011062701 & Giant Starcase & Mist Tral & 2011 & 6 & 27 & 1200 & RF & 22 & 11 & 15 & 21 & 2 & 31 & 12 & 19 & 30 \\
\hline 897 & 2011062901 & Glaclor Point & na & 2011 & 6 & 29 & $9: 30$ & RF & 17 & 2 & 8 & 4 & 2 & 26 & 9 & 16 & 11 \\
\hline 898 & 2011070101 & Gacier Point & Looge Trai & 2011 & 7 & 1 & $2: 41$ & RF & 19 & 6 & 13 & 12 & 2 & 26 & 7 & 17 & 15 \\
\hline 899 & 2011070501 & Corthedral Rocks & Mideclo Cathodral Rock & 2011 & 7 & 5 & $17: 38$ & RF & 22 & 14 & 18 & 17 & 2 & 29 & 16 & 21 & 21 \\
\hline 900 & $\begin{array}{l}2011070502 \\
201070702\end{array}$ & Merced River Gorge & El Portal Road / Blg Oak Fiat Road & 2011 & 7 & $5-6$ & late pmo / eariy am & RF & 22 & 14 & 17 & 16 & 2 & 29 & 16 & 21 & 19 \\
\hline 901 & $\begin{array}{l}2011070701 \\
2010707201\end{array}$ & Glacier Point & Leche Trail & 2011 & 7 & 72 & $7: 06$ & RF & 24 & ${ }^{13}$ & ${ }_{13}^{18}$ & 17 & 2 & 33 & 17 & ${ }^{23}$ & 18 \\
\hline 902 & $\begin{array}{l}2011071201 \\
2011071309\end{array}$ & Cathedral Rocks & Midele Catitedral Rock & 2011 & $7^{7}$ & 12 & $\begin{array}{l}14.47 \\
16.15\end{array}$ & $R F$ & 21 & 8 & ${ }_{12}^{13}$ & 18 & 2 & 29 & 12 & 19 & 29 \\
\hline 903 & $\begin{array}{l}2011071301 \\
2011071302\end{array}$ & 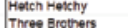 & $\begin{array}{l}\text { Eye in the Sky } \\
\text { Riross Pinnote }\end{array}$ & 2011 & 7 & (13 & 16:57 15 & RF & $\begin{array}{l}16 \\
19\end{array}$ & 7 & ${ }_{12}^{12}$ & ${ }_{13}^{16}$ & 2 & 28 & 年 & ${ }_{18}^{18}$ & ${ }_{21}^{27}$ \\
\hline 904 & $\begin{array}{l}20101071302 \\
2011071001\end{array}$ & Theree Brotiens & Rixon's Pinnacio & 2011 & 7 & 13 & 8.47 & RF & ${ }_{15}^{19}$ & 7 & 12 & ${ }_{6}^{13}$ & 2 & ${ }_{27}^{29}$ & 12 & 19 & ${ }_{12}^{21}$ \\
\hline 908 & 2011081901 & $\begin{array}{l}\text { Union Point } \\
\end{array}$ & Chaper Wel & 2011 & 8 & 19 & 12.30 & $\mathrm{RF}$ & 23 & 12 & 16 & 22 & 2 & 34 & 13 & 23 & 29 \\
\hline 907 & 2011090101 & Cothecral Rocks & Mideclo Catheodral Rock & 2011 & 9 & 1 & 6:15 & RF & 22 & 10 & 16 & 12 & 2 & 33 & 12 & 21 & 13 \\
\hline
\end{tabular}

Figure 5. Example format of "Environmental Conditions" sheet from the rock fall database. Only a small selection of the rock fall events and organizational categories are shown. 
unknown, the earliest day in the range is chosen for the ID; if no range is known, the month and day are set to zeros. The ID numbers are unique to this database; they do not correlate directly with ID numbers used in previous versions of the database (that is, Wieczorek and others, 1992; Wieczorek and Snyder, 2004). The ID numbers in previous versions were assigned in chronological order, and changed in subsequent versions of the database due to the discovery of previously unlisted historical records of rock falls. We discontinued the practice of changing ID numbers to maintain chronological order in favor of the new system, where recently discovered historical rockfalls are assigned a chronologically sequential number referenced to the date of the event. There are therefore three sets of ID numbers, one each for the 1992, 2004, and present inventories. Although only the present ID numbers are referenced in this document, previous version ID numbers are included in the master sheet of the database to assist crossreferencing with previous versions.

In many cases, smaller rock falls occurred for periods of days, weeks, and sometimes months following a large rock fall, making accurate reporting of all associated events difficult. For example, numerous small rock falls continued at Middle Brother for at least one month following two large rock falls on March 10, 1987 (Wieczorek and others, 1995; Wieczorek, 2002). In general, the descriptions of large rock falls (with volumes between 500 and $5000 \mathrm{~m}^{3}$ ) that occurred within a short time period from the same release point are listed as separate events. Information on smaller rock falls is particularly difficult to collect from events occurring at night, or from events that were only heard without being observed, because reports of location and volume can vary widely. In winter, distinctions between ice fall and rock fall are also problematic. Therefore, this inventory lists only those rock falls for which sufficient and reliable descriptive information or physical evidence are available.

\section{Event Location}

Two data columns, labeled "General location" and "Additional location information," provide spatial identification information for events in the inventory database. The general location refers either to one of 21 areas in Yosemite Valley (fig. 3) that are delineated by major natural topographic breaks or cliff features, or to other areas outside Yosemite Valley but still within Yosemite National Park (for example, Hetch Hetchy, Tuolumne Meadows, Tioga Road, and others; fig. 1) . The additional location information refers to a more specific area within each general location and typically references geographic feature names, well-known developed infrastructure, or rock climbing areas (for example, Middle Brother, Yosemite Falls Trail, and Chapel Wall, which are located within the Three Brothers, Yosemite Falls, and Union Point general locations, respectively). These more specific locations are marked with two-letter character designations in figures 1 and 3 and are referenced to both formal and informal geographic names in table 1. A third column, labeled "Figure location reference," is included in the database to direct users to the appropriate figure in which the general location of these features can be found.

Where available, additional detailed location information is provided in the narratives. Despite the identification of specific locations of features on the maps, it is imperative that users recognize the limitations of these data in precisely locating the rock fall events - whereas in some cases the exact location of the rock fall is known to within several meters, in many cases, the only spatial location information known about an event is that it occurred somewhere in the vicinity of a trail or other landmark. In some of these cases, particularly for those occurring early in the database history, the spatial location can only be identified to within an area of several square kilometers.

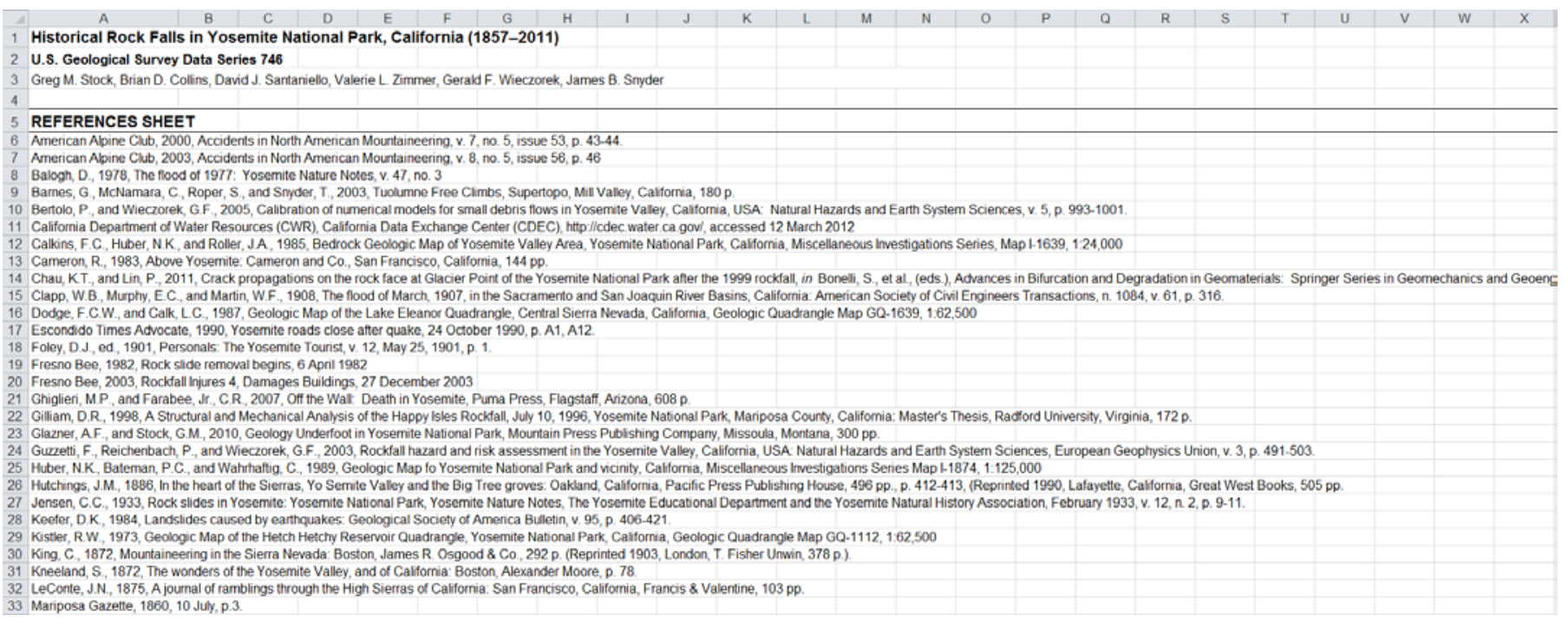

Figure 6. Example format of "References" sheet from the rock fall database. Only a selection of the references are shown. 
Table 1. Geographic names ${ }^{1}$ and labels of select locations in Yosemite National Park referenced ${ }^{2}$ in figures 1 and 3.

\begin{tabular}{|c|c|c|c|c|c|}
\hline Label & Geographic name & Label & Geographic name & Label & Geographic name \\
\hline $4 \mathrm{M}$ & Four Mile Trail (F3-17) & $\mathrm{GC}$ & Grouse Creek (F1) & PJ & Pat and Jack Pinnacle (F1) \\
\hline $4 \mathrm{~W}$ & Camp Four Wall (F3-4) & GD & Gardiner Camp (F1) & PL & Parkline (F1) \\
\hline AP & Ahwiyah Point (F3-11) & GP & Glacier Point (F3-16) & PP & Panorama Point (F3-14) \\
\hline $\mathrm{AR}$ & Arch Rock (F1) & GS & Gunsight (F3-20) & PR & Pulpit Rock (F3-1) \\
\hline AS & Arrowhead Spire (F3-6) & GV & Grapevine (F1) & PV & Pate Valley (F1) \\
\hline $\mathrm{BD}$ & Basket Dome (F3-9) & GZ & Grizzly Peak (F3-12) & PW & Porcelain Wall (F3-11) \\
\hline $\mathrm{BE}$ & Benson Pass (F1) & $\mathrm{HF}$ & Hidden Falls (F3-10) & QD & Quarter Domes (F3-10) \\
\hline $\mathrm{BF}$ & Bridalveil Fall (F3-20) & $\mathrm{HI}$ & Happy Isles (F3-16) & RA & Royal Arches Cascade (F3-7) \\
\hline $\mathrm{BL}$ & Bernice Lake (F1) & HK & Housekeeping Camp (F3-16) & $\mathrm{RC}$ & Rail Creek (F1) \\
\hline $\mathrm{BP}$ & Badger Pass (F1) & $\mathrm{HM}$ & Hodgdon Meadow (F1) & $\mathrm{RD}$ & Red Peak Pass Trail (F1) \\
\hline $\mathrm{BR}$ & Mount Broderick (F3-13) & HT & Horse Tail Falls (F3-3) & $\mathrm{RF}$ & Ribbon Falls (F3-2) \\
\hline $\mathrm{BS}$ & Beehive Switchbacks (F1) & IC & Illilouette Creek (F3-15) & $\mathrm{RP}$ & Reed's Pinnacle (F1) \\
\hline $\mathrm{BU}$ & Bunnell Point (F1) & LB & Little Blue Slide (F1) & $\mathrm{RS}$ & Rostrum (F1) \\
\hline CA & Castle Cliffs (F3-6) & $\mathrm{LC}$ & Lower Cathedral Rock (F3-20) & RT & Rattlesnake (F1) \\
\hline $\mathrm{CB}$ & Church Bowl (F3-7) & LE & Lehamite Falls (F3-6) & RW & Rhombus Wall (F3-7) \\
\hline $\mathrm{CC}$ & Cookie Cliff (F1) & LF & Lower Yosemite Falls (F3-5) & $\mathrm{RX}$ & Rixon’s Pinnacle (F3-4) \\
\hline $\mathrm{CD}$ & Cascades (F1) & LG & LeConte Gully (F3-16) & SB & Sunnyside Bench (F3-5) \\
\hline $\mathrm{CF}$ & Chilnualna Falls (F1) & LI & Liberty Cap (F3-13) & $\mathrm{SC}$ & Sentinel Creek (F3-18) \\
\hline CG & Cathedral Gully (F3-20) & LR & Lake Eleanor Road (F1) & SD & Stanford Point (F3-21) \\
\hline CK & Clark Point (F3-13) & LT & Ledge Trail (F3-16) & $\mathrm{SE}$ & Southeast Face (F3-3) \\
\hline $\mathrm{CL}$ & Cloud's Rest (F1) & LV & Lee Vining Canyon (F1) & SF & Staircase Falls (F3-16) \\
\hline $\mathrm{CP}$ & Cathedral Peak (F1) & $\mathrm{MB}$ & Middle Brother (F3-4) & SN & Snow Creek Trail (F3-9) \\
\hline CQ & Chinquapin (F1) & $\mathrm{MC}$ & Middle Cathedral Rock (F3-20) & SP & Sierra Point (F3-12) \\
\hline $\mathrm{CR}$ & Columbia Rock (F3-5) & MD & Moraine Dome (F1) & ST & Sierra Point Trail (F3-12) \\
\hline CS & Cathedral Spires (F3-20) & MG & Muir Gorge (F1) & SW & Southwest Face (F3-3) \\
\hline $\mathrm{CV}$ & Curry Village (F3-16) & ML & Mirror Lake Trail (F3-11) & TA & Taft Point (F3-19) \\
\hline $\mathrm{CW}$ & Chapel Wall (F3-17) & MM & Medial Moraine (F3-11) & $\mathrm{TC}$ & Tiltill Creek (F1) \\
\hline DA & Mount Dana (F1) & MO & Mono Grade (F1) & TD & Turtleback Dome (F1) \\
\hline DR & Dog Rock (F1) & MP & Manure Pile Buttress (F3-3) & $\mathrm{TF}$ & Tamarack Flat (F1) \\
\hline EB & East Buttress (F3-3) & MT & Mist Trail (F3-13) & $\mathrm{TP}$ & Tenaya Peak (F1) \\
\hline EG & Eagle Peak (F3-4) & MW & Mount Watkins (F3-10) & $\mathrm{TU}$ & Tueeulala Falls (F1) \\
\hline EL & Elephant Rock (F1) & ND & North Dome (F3-8) & UF & Upper Yosemite Falls (F3-5) \\
\hline EP & El Portal (F1) & NF & Nevada Fall (F3-13) & VF & Vernal Fall (F3-13) \\
\hline ER & Eagle Rock (F3-17) & NO & Nose (F3-3) & WA & Washington Column (F3-8) \\
\hline ES & Eye in the Sky (F1) & NW & Northwest Face (F3-11) & WC & Wawona Campground (F1) \\
\hline FB & Fifi Buttress (F3-21) & OB & Old Big Oak Flat Rd (F3-2) & WF & Wapama Falls (F1) \\
\hline FM & Fort Monroe (F1) & $\mathrm{OC}$ & Old Coulterville Road (F1) & WP & Windy Point (F1) \\
\hline FR & Foresta Road (F1) & OI & Old Inspiration Point (F3-21) & WS & Washburn Slide (F3-21) \\
\hline FT & Yosemite Falls Trail (F3-5) & PB & Pohono Bridge (F3-21) & WT & Wawona Tunnel (F3-1) \\
\hline FW & Forbidden Wall (F3-5) & $\mathrm{PC}$ & Piute Creek (F1) & YP & Yosemite Point (F3-5) \\
\hline GA & Glacier Point Apron (F3-16) & $\mathrm{PF}$ & Profile Cliff (F3-19) & & \\
\hline
\end{tabular}

${ }^{1}$ Both formal and informal geographic names are used to describe locations.

${ }^{2}$ Text in parentheses refers to the figure number (for example, F1 for fig. 1) in which the location is identified by the 2-letter label. For locations within Yosemite Valley, the number following the figure number identifies the subarea delineated in figure 3. 
The dual-location format differs from previous versions of the database that listed only detailed locations for rock falls. Whereas the previous method had the advantage of providing detailed spatial information within the "Location" column, it proved to be a disadvantage for those not intimately familiar with the many place names of Yosemite National Park. Listing of only detailed locations also often made spatial analyses of general areas difficult; for example, rock falls from the Glacier Point area were variously listed as occurring at "Washburn Point," "Happy Isles," "Curry Village," "Staircase Falls," "LeConte Gully," and so on, complicating analyses of rock falls from the Glacier Point area. The new general and additional location information columns therefore provide more clarity on the locations of rock falls, and allows users to sort and view events by both general and more specific areas of interest. For completeness, any spatial information previously included in the "location" column remains preserved in the narrative descriptions.

\section{Type of Slope Movement}

Types of slope movement are classified using the system of Varnes (1978), which is based on the type of material involved in movement (rock, soil, or debris) and the dominant type of movement (falling, sliding, toppling, flowing, or a combination thereof). Most historical reports either identify the type of slope movement or are sufficiently descriptive so that the type of slope movement can be inferred based on examination of the form and character of the source area or resulting deposits. Mass movements involving rock falls or rock slides are the most numerous types of slope movement recorded in Yosemite National Park (89 percent). Debris flows, debris slides, and earth or debris slumps have been less frequently reported. This may be due in part to inconsistent recording of these events prior to 1990 , but more consistent recording after 1990 indicates that these events do in fact occur less frequently than do rock falls and rock slides.

\section{Season}

Evaluating the seasonality of rock falls can improve understanding of rock-fall triggering mechanisms (see, for example, Luckman, 1976). Accordingly, the database lists the season of each rock fall or other slope movement event, where known, under a column titled "Season." This provides a measure of time for each event in the database, even if the exact date is not known (for example, for instances when rock debris is encountered on a trail and only reported some time after the rock fall has occurred). Winter is defined as the period between the winter solstice and spring equinox (December 21-22 through March 20-21), spring as the period between the spring equinox and summer solstice (March 20-21 through June 20-21), summer as the period between the summer solstice and fall equinox (June 20-21 through September 22-23), and fall as the period between the fall equinox and winter solstice (September 22-23 through December 21-22). Due to planetary physics (that is, the tilt of the Earth with respect to the sun), the exact dates of equinoxes and solstices vary from year to year; for consistency we define all transitions as occurring at 12:01 PST on the second day listed (for example, 12:01 a.m. on December 22). Listing rock falls by season allows users to perform seasonal correlations of other rock fall parameters using a standardized data set and reduces the possibility of conflicting interpretations of the data.

\section{Date and Time}

Dates and times of occurrence of historical rock falls are known with varying degrees of accuracy. The larger and more damaging events typically attract more attention and are often noted with precision to the day, hour, and sometimes minute.

Recent events documented with digital cameras (whose clocks are set correctly) may even record timing with subminute precision. However, some events, such as those observed after the winter or spring seasons, can only be associated with several months within a particular season. As Yosemite Valley visitation has increased and as park visitors, employees, and residents have become more aware of rock falls, the precise timing of rock falls has been more regularly reported. At present, the timing of relatively large rock falls occurring in Yosemite Valley is usually reported to the minute, but smaller rock falls occurring in more remote areas outside of Yosemite Valley may only be reported to the day or month.

To allow for easy sorting of the database, the dates for each event are subdivided into three separate columns of year, month, and day. Because some events in the database do not report an exact day, month, or even year, this division allows users to conduct general temporal analyses of rock falls. As noted previously, events that could not be located in time within a 5-year period are excluded from this database.

All times for rock fall events are reported in 24-hour time and standardized to Pacific Standard Time (PST) rather than to local time (for example, Pacific Daylight Time, PDT). In earlier editions of the database, event times were recorded in the local time of Yosemite National Park with no distinction made between PST and PDT. However, this earlier convention can pose problems when events occur near the switch from PST to PDT, in that they might be assigned the same exact time. Local time is still commonly reported in the narrative descriptions, but the official (PST) time is reported in the "Time" column.

To standardize all events in the inventory, we reviewed the changes in policy regarding PST and PDT in California beginning in 1918, when PST became the official time of California (Douma, 2008; State of California, 1949, 1962, 2013). We accounted for all changes in dates and times marking the start and end of PDT throughout this time period. Because of the conversion from local PDT to PST, three of the events (Event IDs 1943031801, 1980011302, and 1982102502) also changed dates and are now reported as occurring one day prior to the dates reported in the previous 
(Wieczorek and Snyder, 2004) version of this database. In addition, one new event not included in prior databases and that was reported to have occurred on August 5, 1957, at midnight is reported as Event ID 1957080401 with a time of 23:00 PST on August 4, 1957. The only specific times reported for events prior to 1918 are by John Muir for earthquaketriggered rock falls on March 26, 1872 (IDs 1872032601 and 1872032606; Muir, 1912). These times cannot be standardized to PST and are reported directly as John Muir recorded them.

\section{Estimated Volume}

Rock fall volume is an important component of many types of hazard assessments, and particularly those that involve computer simulations and probabilistic assessments based on volume-frequency relations (for example, Guzzetti and others, 2003, Dussauge-Peisser and others, 2002; Dussauge and others, 2003, Stock and others, 2012) as it can strongly influence calculated rock-fall runout distances. Rock-fall volumes are reported here in cubic meters. We intentionally use the term "Estimated volume" to reflect the uncertainty associated with the majority of volumes reported in the database. The volume or weight of a rock fall is sometimes mentioned in historical reports, often in terms of cubic yards or pounds, but more frequently is reported in only relative size terms such as "small" or "large."

Several factors complicate the determination of accurate volume estimates from rock-fall descriptions. Descriptions of some rock falls include incomplete estimates of volume, such as the length of trail blocked by rock-fall debris. In order to estimate volume, such descriptions require additional assumptions (for example, debris width, thickness, and porosity) that are often difficult to evaluate. An historical estimate of rock-fall volume blocking a road may represent only a small fraction of the total volume because other portions of the rock fall may have stopped uphill or been transported downhill beyond the road. In such cases, the reported volume is a minimum estimate. In general, volumes reported prior to 1980 are depositional volumes; since 1980 an effort has been made to estimate volumes from source areas. In certain instances, older historical rock-fall volumes have been updated based on field or remote sensing measurements of their source areas or deposits. Other descriptions lack any information relative to size. Historical volume records reported here generally refer to final volumes of deposition rather than detached volumes. If tonnage was reported, volume was calculated assuming an average unit weight of $2,700 \mathrm{~kg} / \mathrm{m}^{3}\left(168 \mathrm{lb} / \mathrm{ft}^{3}\right)$. Inaccuracy in estimating volume can also result from differences in average unit weight between intact bedrock and rock-fall deposits.

Momentum transfer can also complicate estimates of rock fall volumes. The removed volume at a rock-fall scar is at most a measure of the initial minimum volume from the source area; during descent down the cliff face, a transfer of momentum can mobilize additional intact rock from bedrock ledges or talus which can substantially increase the overall volume of mobilized material. For example, the reported volume of the Ahwiyah Point rock fall on March 28, 2009 (ID 2009032801, located within the Half Dome general location; see fig. 3), consists of approximately $25,400 \mathrm{~m}^{3}$ from the source area, $2,000 \mathrm{~m}^{3}$ from intermediate blocks dislodged after sliding, and $19,300 \mathrm{~m}^{3}$ dislodged when the initial rock mass struck bedrock ledges as it moved down the cliff face (Zimmer and others, 2012). Thus, in some events the reported volume may differ considerably from the initial source area volume.

When a series of rock falls occurred in the same location, but their individual volumes could not be discerned from one another, only a total volume estimate is provided. For example, on March 10, 1987, a large rock fall from the face of Middle Brother (Three Brothers general location) spread rapidly across the talus cone at its base, covered the adjacent road (Northside Drive), and sent a few boulders across the Merced River (ID 1987031001). Another large rock fall occurred later that day from the same source area (ID 1987031002). The combined volume of these two rock falls is an estimated $600,000 \mathrm{~m}^{3}$ and represents the largest event in the database. This value is listed as a single cumulative volume in the entry for the first event (ID 1987031001), whereas the volume for ID 1987031002 is listed as "See ID 1987031001" indicating that the reported value for the preceding event is a summation of the two rock falls. In only a few instances were rock-fall volumes precisely determined (for example, IDs 2008100701-2008100801, 2009032801, 2009082601-2009091401), usually by using repeat laser scanning or other quantitative remote sensing techniques (see, for example, Stock and others, 2011, 2012; Zimmer and others, 2012). Considering the qualifications regarding volume estimates, the volumes reported in this inventory, especially those prior to 1980 , are best viewed as order-of-magnitude estimates unless specific volume or weight data are reported, or if the dimensions of the source area or entire deposit were more accurately measured, as indicated in the narratives or relevant publications.

In addition to quantitative estimates of volume, we also characterize the range of volumes in relative terms, ranging from "extremely small" to "extremely large" (table 2). A correlation between these relative volume terms and the range of volume and assigned median volume was developed by Wieczorek and others (1992) based on detailed examination of specific rock falls and the overall distribution of rock-fall volumes, and was continued in the database of Wieczorek and Snyder (2004). The assignment of volumes based on qualitative terms provides a consistent method for estimating volumes across the entire inventory of rock falls.

For many rock falls, especially those that occurred early in the reporting period, event volumes are not well known, and a median volume (logarithmic scale) is reported for specific order-of-magnitude estimates (table 2). Rather than reporting volume ranges in the "Estimated volume" column, we report the median volume there and show the range in the minimum and maximum estimate columns. In some cases, the volume of a rock fall is not known exactly but can be constrained by a range that is more precise than an order of magnitude; in those cases, the minimum and maximum estimates are also shown. Finally, in some cases the volume is well-constrained and the estimate 
is considered to be reasonably accurate; in those cases the minimum and maximum estimates are intentionally left blank.

\section{Rock Units}

Rock units associated with rock-fall source areas are determined in most recent events by on-site inspection of source areas and the resulting new talus beneath these areas. For older events and for events in which the general rock fall location is known, but no definite source area or fresh talus identified, we cross-referenced the event locations with published geologic maps (Kistler, 1973; Calkins 1985, Dodge and Calk, 1987; Huber and others, 1989; Peck, 2002) to determine source area rock units. In some cases, the exact rock unit is indeterminate either because the exact location of the rock fall is unclear, or because there is a mixture of different rock units in a particular area (for example, Glacier Point contains large areas of both Half Dome Granodiorite and granodiorite of Glacier Point); in these cases, more than one geologic unit is listed.

The oldest rock unit listed in the database is undivided metamorphic or metasedimentary rock (Pzme), and is found at a few small enclaves inside the park (for example, along Wawona Road) and just outside the park (for example, the Merced River gorge near El Portal). The remainder of the rock is granitic and dioritic rock of Cretaceous age and is part of the larger Sierra Nevada batholith (Bateman, 1992). The database includes rock falls that have occurred from rocks representing 19 mapped intrusive units (table 3). Some slope movement events, such as debris flows, debris slides, debris slumps, earth slides, and earth slumps, consist primarily of previously deposited material that has remobilized. In these cases, the rock unit is designated as Quaternary colluvium and (or) talus (Qat).

\section{Probable Triggering Condition(s)}

We assign a probable triggering condition for each rock fall or other slope movement based on available evidence at the time of the event. Referring to landslides in general, Wieczorek (1996) defines a trigger as "an external stimulus such as intense rainfall, earthquake shaking, volcanic eruption, storm waves, or rapid stream erosion that causes a near-immediate response in the form of a landslide by rapidly increasing the stresses or by reducing the strength of the slope materials." This definition encompasses two concepts: the environmental conditions under which the event occurs, and the physical processes and mechanistic forces that result in movement of the rock or soil. Whereas the majority of triggering conditions can be inferred through observations or temporal coincidence, triggering mechanisms can, in most cases, only be determined by detailed monitoring and instrumentation of rock fall detachment surfaces (see discussion in Wieczorek and others, 2008). Triggering mechanisms include such processes as increased water pressure from precipitation-induced seepage, inertial forces from seismic shaking, and fracture propagation
Table 2. Relative size categories of rock falls in Yosemite National Park.

\begin{tabular}{lcc}
\hline \multicolumn{1}{c}{ Relative size } & Volume range $\left(\mathbf{m}^{3}\right)$ & $\begin{array}{c}\text { Median volume } \\
\left(\mathbf{m}^{3}\right)\end{array}$ \\
\hline Extremely small & $0-0.5$ & 0.2 \\
Very small & $0.5-5$ & 2 \\
Small & $5-50$ & 20 \\
Medium & $50-500$ & 200 \\
Large & $500-5,000$ & 2,000 \\
Very large & $5,000-50,000$ & 20,000 \\
Extremely large & $50,000-500,000$ & 200,000 \\
\hline
\end{tabular}

Table 3. Rock units comprising rock falls in Yosemite National Park.

\begin{tabular}{|c|c|}
\hline Geologic symbol & Rock unit \\
\hline Qat & colluvium and/or talus \\
\hline Kcp & Cathedral Peak Granodiorite ${ }^{1}$ \\
\hline Khd & Half Dome Granodiorite ${ }^{2}$ \\
\hline Kgp & granodiorite of Glacier Point ${ }^{2}$ \\
\hline $\mathrm{Ks}$ & Sentinel Granodiorite ${ }^{2}$ \\
\hline Kyc & granodiorite of Yosemite Creek ${ }^{2}$ \\
\hline Kgi & quartz diorite of Mount Gibson ${ }^{3}$ \\
\hline Krd & granodiorite of Red Devil Lake ${ }^{1}$ \\
\hline $\mathrm{Kbv}$ & Bridalveil Granodiorite $^{2}$ \\
\hline Klt & Leaning Tower Granite ${ }^{2}$ \\
\hline Kic & granodiorite of Illilouette Creek ${ }^{2}$ \\
\hline Kid & quartz diorite $^{1}$ \\
\hline $\mathrm{Kt}$ & Taft Granite ${ }^{2}$ \\
\hline Krm & granodiorite of Rancheria Mountain \\
\hline $\mathrm{Kec}$ & El Capitan Granite ${ }^{2}$ \\
\hline Ktf & granodiorite of Tueeulala Falls ${ }^{4}$ \\
\hline $\mathrm{Ka}$ & granodiorite of Arch Rock ${ }^{2}$ \\
\hline Kga & tonalite of the Gateway ${ }^{1}$ \\
\hline Kdg & diorite of the Rockslides ${ }^{5}$ \\
\hline $\mathrm{Kg}$ & granitic rocks, undivided $^{1}$ \\
\hline Pzme & metasedimentary rock, undivided ${ }^{1}$ \\
\hline $\begin{array}{l}{ }^{1} \text { Nomenclature from } \\
{ }^{2} \text { From Peck (2002). } \\
{ }^{3} \text { From Kistler (1973) } \\
{ }^{4} \text { From Dodge and Ce } \\
{ }^{5} \text { From Calkins (1985 }\end{array}$ & Huber and others (1989). \\
\hline
\end{tabular}


from thermal heating or freeze-thaw cyclic forces. In general, none of these processes have been directly measured at particular rock fall sites in Yosemite and thus our assignment of triggering mechanisms must be considered tentative.

We use the term "probable" with respect to triggering conditions to reflect the inherent uncertainty in assigning exact triggers. For example, a very light rainfall event may be temporally coincident with a rock fall, but the amount of rainfall might not be sufficient to cause a change in the stability of the rock mass. Similarly, a period of very hot temperatures might be associated with a rock fall but cannot be strictly determined to have triggered failure.

Wieczorek (1996) noted the importance of timing in assigning triggers, stating that "the requisite short time frame of cause and effect is the critical element in the identification of a landslide trigger." Some rock falls recorded in the accompanying database were observed by eyewitnesses and directly associated in time with triggers such as rainstorms or earthquakes. In other accounts, although the rock fall was not observed as it occurred, the trigger was reported to be a temporally associated event, such as an earthquake, rain storm, period of rapid snowmelt, wind, or period of extreme freezethaw conditions. In this manner, the triggering condition is inferred primarily by temporal coincidence. As such, assigned triggers should be considered provisional assessments subject to change pending more detailed analysis. However, in general, it is unrealistic to assume that more information will be obtained for the vast majority of the events reported in the database.

We assign sixteen types of triggering conditions (with associated abbreviations) to the event database, described in the following sections.

\section{Earthquakes (EO)}

Earthquakes generate seismic ground shaking that can result in inertial forces to rock and soil masses, causing failure (see, for example, Keefer, 1984). Earthquakes can also cause cyclic deterioration of the strength that initially keeps rock or soil masses stable. We assigned earthquake (EQ) triggers to events by temporal correlation (within seconds to minutes) with observed or measured ground shaking. We evaluated earthquake activity based on information provided by the USGS National Earthquake Information Center (USGS, 2011).

\section{Precipitation (P), Rain-on-Snow (R/S), Snow Melt (SM)}

Precipitation consisting of rain and snow, rain falling on snow with resulting snow melt, and seasonal snow melt can lead to erosion of interstitial material between originally stable rock masses, reduction of tensile stresses in soils, and development of water pressures within both soil and rock masses. We assigned these triggers to events by temporal correlation with observed or measured weather and temperature conditions. We assign a precipitation $(\mathrm{P})$ trigger collectively to both rain and snow events because both may occur during a single storm and often vary greatly depending on elevation. We further distinguish rain-on-snow $(\mathrm{R} / \mathrm{S})$, and snow melt (SM) conditions occurring at the time of a rock fall, when known, to highlight particular types of seepage conditions (for example, rain-on-snow conditions can sometimes generate greater runoff than precipitation alone). Problems assigning precipitation triggers to a particular event are primarily with timing; infiltration of rainfall may take days or weeks following storm events, and snowmelt may occur even more gradually over several months during seasonal warming.

\section{Freeze-Thaw (F/T)}

Freeze-thaw conditions consist of temperature fluctuations around $0{ }^{\circ} \mathrm{C}$ that result in the freezing of water and thawing of ice within rock fractures. The approximate 9 percent volumetric expansion of water into ice during freezing can lead to increased stresses in rock fractures that force partially detached rock masses to move outwards from the cliff face. Thawing conditions can release destabilized blocks that were previously frozen in place (see, for example, Matsuoka and Sakai, 1999). We assign freeze-thaw (F/T) triggers to events by temporal correlation with observed or measured weather and temperature conditions.

\section{Snow Avalanche (SA)}

Snow avalanches can trigger rock falls by directly impacting unstable rock masses along their downward trajectory or by mobilizing unstable rock masses through the basal shear stress they impart to the surfaces that they move over. We assign a snow avalanche (SA) trigger to events by temporal correlation with observations or documented reports of snow avalanches.

\section{Wind (W)}

Wind can loosen rock masses by causing pressure differences between interior fractures and exterior surfaces, or by forcing trees to leverage root networks embedded in rock masses. We assign a wind (W) trigger based on temporal correlation with observed windy conditions (typically winds in excess of $30 \mathrm{~km} /$ hour).

\section{Lightning (L)}

Lightning can weaken and detach intact rock masses by the discharge of electrostatic energy during a strike, sometimes through superheating of water into steam that causes increased pressures in rock fractures. We assign a lightning (L) trigger based on temporal correlation with observed or reported lightning strikes. 


\section{Root Wedging (RW)}

Root wedging consists of the expansion of rock fractures from the growth of vegetation roots. This can cause either an increase in stress to the interior of rock masses or cause a decrease in rock fracture strength by the breaking apart of rock mass bonds. We assign a root wedging (RW) trigger to rock falls based on inferred correlation with observations that showed evidence of root growth in bounding rock fractures but with no other identified trigger.

\section{Thermal Stress (TS)}

Thermal stress as a rock-fall trigger consists of the expansion and contraction, and resulting deformation, of rock masses from cyclical changes in temperature (see, for example, Vargas and others, 2012). Although not reported as a rock fall trigger in previous versions of this database (Wieczorek and Snyder, 2004; Wieczorek and others, 1992), recent research (for example, Collins and Stock, 2010) has shown that thermal stresses may be responsible for the deformation and subsequent failure of thin, exfoliation flakes formed along sheeting joints, a feature common in Yosemite. Further, this research has shown that there may be a temporal correlation of rock falls with summer afternoons and early evenings in which temperatures are typically at their maximum during the year. We therefore assign a thermal stress (TS) trigger to rock falls based on inferred correlation with periods of measured high temperatures and strong daily temperature gradients, and for which no other obvious trigger could be identified.

\section{Crack Propagation (CP)}

Crack propagation is caused by changing stress conditions within a rock mass. Although these changes can be induced by a number of factors, including water or ice as previously identified, we reserve the assignment of a crack propagation trigger to conditions where a rock fall can be plausibly linked to stress redistribution and cracking following an earlier failure of an adjacent rock mass. This can occur, for example, when a rock fall occurs in an overhanging region and the loss of support results in a new stress condition that leads to an additional rock fall (for example, progressive rock falls from the Rhombus Wall in 2009-2010; Stock and others, 2012). The cracking observed by Wieczorek and Snyder (1999) and modeled by Chau and Lin (2011) that followed the June 13, 1999, Curry Village rock fall (Glacier Point general location) is another example of this type of process. Assigning temporal coincidence for crack propagation triggers can be difficult because cracks may take days, weeks, months, or longer to propagate through rock masses. However, in some instances, cracking noises were heard just prior to, or just after, a rock fall occurred, indicating crack propagation. Therefore, we assign a crack propagation $(\mathrm{CP})$ trigger when this condition was suggested by the adjacent proximity of new rock falls to existing source areas, the presence of cracking sounds, and where no other obvious trigger could be identified. Because of the difficulty of reliably identifying crack propagation conditions, this trigger is considered particularly tentative at this time.

\section{Blasting (BL), Construction (C)}

Human-induced blasting of rock for construction or hazard mitigation purposes can induce vibratory forces and cyclical strength degradation similar to earthquakes such that rock masses may become destabilized. Similarly, human slope disturbance in the form of construction (but not including blasting) can cause undercutting and destabilization of rock masses that may lead to rock falls and other slope movements. We assign a blasting (BL) or construction (C) trigger to events by temporal correlations (usually within seconds to minutes) with observed or reported blasting and construction activities.

\section{Ground Vibration (GV)}

Ground vibration induced from other rock falls can trigger subsequent rock falls by causing vibratory forces and cyclical strength degradation similar to earthquakes such that rock masses may become destabilized. We assign a ground vibration (GV) trigger to events by temporal correlation of rock falls from nonadjacent rock masses, and in the absence of any documented seismicity.

\section{Unrecognized (UNR) and Unknown (UKN)}

Referring to landslides in general, Wieczorek (1996) noted that some landslides "may occur without an apparent attributable trigger because of a variety of combination of causes, such as chemical or physical weathering of materials, that gradually bring the slope to failure." In cases where rock falls in Yosemite were closely observed, but the triggers are still unrecognized, they are listed in this database with an unrecognized (UNR) trigger. The concept of unrecognized triggers is not unique to Yosemite and this category has been included in other rock fall inventories (for example, Sanderson and others, 1996). Unrecognized triggers are distinguished from unknown triggers where, in the latter case, little to no information is known about the event. In cases where a trigger is unreported and no additional information regarding possible triggering conditions is given, they are listed in this database with an unknown (UKN) trigger. Rock falls whose timing is not well known are also assigned unknown triggers.

\section{Impacts to Humans}

The impacts of a particular rock fall to humans are categorized in three different ways: number of human fatalities, number of human injuries, and damage to trails, roads, 
structures, utilities, or other infrastructure or assets. The degree of seriousness of injuries was not characterized separately in most historical accounts; the number of injuries recorded in the database therefore includes both minor and major injuries. For a more comprehensive evaluation of the hazards or risks posed by these rock falls, additional details of reported damage are provided in the narrative descriptions. In some narrative descriptions, the estimated costs of damage or repairs were included (reported for the time that the event occurred, that is, uncorrected for inflation), but we did not attempt to characterize these with respect to the magnitude of damage. Likewise, we did not distinguish severe from minimal damage caused by rock falls. For example, severe damage from a rock fall may have torn apart or covered a large portion of a road, requiring days or weeks for repairs, whereas in other cases, only a few small rocks falling onto a road may have resulted in the road being closed for shorter periods of time until the site was judged safe to reopen. The narratives provide additional qualitative information about the severity of damage.

Within the database, fatalities and injuries are designated with the number of persons killed or injured. When no one was affected, a "0" was assigned. Review of historical information between publication of this version of the database and the previous version identified 3 additional rock-fall-related human fatalities and numerous additional rock-fall-related injuries, bringing the total number of documented fatalities to 15 and the total number of injuries to 85 from 1857 through 2011.

\section{Published References}

Within the accompanying database, we provide a listing of published references relevant to the rock falls and other slope movement events reported in this database. These include papers from scientific journals, conference proceedings and abstracts, published reports from the USGS and other sources, Master's theses and Ph.D. dissertations, and newspaper articles. In cases of large or otherwise notable rock falls, many newspaper articles exist; in those cases, we reference one or two examples.

The published references column in the database has been updated from the previous version (Wieczorek and Snyder, 2004) to include additional references for rock falls occurring between 1857 and 2004, and to include new material for rock falls occurring after 2004. We have included all published references in this column, even if information in them is not specifically cited in the "Narratives" column. Full citations for references listed in the "Published References" column are provided in the third sheet of the database, titled "References."

\section{Narratives}

The "Narratives" column in the accompanying database and the accompanying file, "Yosemite_rock_fall_database_ narratives_1857-2011.pdf" (see example in fig. $\overline{7}$ ), contains written descriptions of the events, where available. These descriptions vary greatly in length and detail. Descriptions of rock falls were compiled using both published and unpublished information. The many sources of unpublished information include field notes, internal NPS, USGS, and other reports, memoranda, emails, website forums, and oral communications from park visitors, employees, and residents.

The first collection of rock-fall information was an unpublished rock-fall inventory prepared by Yosemite National Park Historian James Snyder (NPS, unpub. data, 1990). Subsequent investigations by Wieczorek and others (1992) and Wieczorek and Snyder (2004) derived additional historical rock-fall information from a variety of sources. These sources include, among others, (1) historical publications, such as those by geologists Josiah Whitney (Whitney, 1868) and Joseph LeConte (LeConte, 1875); (2) the unpublished notes, journals, and letters of John Muir from the Holt-Atherton Collections, University of Pacific Libraries, Stockton, California; (3) the Guardians' Reports, Cavalry Administration Reports, and the Superintendent's Monthly Reports of Yosemite National Park from the Yosemite Research Library and at the National Archives in Washington, D.C.; and (4) the field notes and draft maps of Francois Matthes at the USGS Photo Library and Field Records in Denver, Colorado, and Matthes' personal diaries at the Bancroft Library, University of California, Berkeley. Beginning in the 1980s, rock falls were generally documented by USGS and/or NPS personnel in field notes, letters, and memoranda. Information pertaining to most rock falls occurring since 2005 are recorded in the field notebooks and digital files of the Yosemite National Park geologist. Other unpublished sources are available for examination at the Yosemite Research Library in Yosemite Valley.

As described previously, rock falls from the same source area that occurred at observed separate times, even only several seconds apart, are listed as separate events (for example, ID 1996071001, 1996071002); however, the description of the several events is sometimes combined for continuity in the narratives, (for example, IDs 2003060601-2003062901). Finally, in some cases, photographs or maps are referenced in the descriptions of the rock falls from the cited sources; these photographs or maps are not included in this inventory, but are available for examination in the Yosemite Research Library in Yosemite Valley, or in the files of the Yosemite National Park geologist.

\section{Environmental Conditions}

To further evaluate the assigned probable triggering conditions, we compiled temperature and precipitation data for each rock fall starting in October 1985 (the time of earliest available meteorological data from nearby stations) for a total of 537 events and tallied this data in the second sheet of the Excel spreadsheet, titled "Environmental Conditions." We acquired data from the California Department of Water Resources (CDWR, 2010) for five meteorological stations in Yosemite (fig. 1): four stations are located on the rim surrounding Yosemite Valley-Gin Flat (GIN), Crane Flat (CFL), Ostrander (STR), and Mariposa Grove (MPG) - and 
one station is located in Yosemite Valley proper (YYV). Data presented for the floor of Yosemite Valley (1,215 m elevation) are only available since December 1998 when the YYV station started operating.

We calculated minimum, maximum, and average temperatures for the 24 hours prior to the rock fall and assigned the temperature at the time of the rock fall for two locations, the floor and rim of Yosemite Valley. We include both locations to highlight the winter temperature inversion and summer "oven" effect that produces lower and higher temperatures, respectively, on the floor of Yosemite Valley than might otherwise be expected. Temperature statistics for the rim of Yosemite Valley (mean elevation 2,377 m) are elevation-corrected averages of available data from the four stations surrounding Yosemite Valley (GIN, CFL, STR, and MPG). Temperature is corrected for elevation by assuming an ambient temperature gradient of $-0.65{ }^{\circ} \mathrm{C}$ per $100 \mathrm{~m}$ of elevation (Lundquist and Cayan, 2007). We assigned cumulative seasonal precipitation (defined as July 1 to June 30 ) and preceding 30 -day, preceding 72 -hour, and preceding 24-hour precipitation to each rock fall using data from the Yosemite Valley station (after 1998) and the Gin Flat station (for 1985-1998). It should be noted that not all of the rock falls were assigned an environmental condition as there are rock falls with unknown dates, and also time periods when the meteorological stations were not operational.

\section{Summary}

The inventory database presented herein provides detailed information on 925 rock falls and other slope movement events in Yosemite National Park spanning more than 150 years. Since deglaciation occurred some 15,000 to 19,000 years ago, rock falls have been the dominant geologic process contributing to landscape erosion; this is particularly true for the glacially steepened cliffs of Yosemite Valley. Rock falls and related events can sometimes pose a threat to the visitors, employees, and residents of Yosemite National Park. In addition to providing pertinent information for use in scientific rock fall studies, the inventory database serves as a reminder of the common occurrence of rock falls in steep landscapes. The database therefore not only provides valuable information for understanding rock falls in Yosemite National Park, and for mitigating the resulting rock-fall hazard and risk, but can also improve understanding of rock-fall processes worldwide.

\section{Acknowledgments}

We are indebted to the numerous park employees, residents, and visitors who provided eyewitness accounts, photographs, and descriptions of rock fall and other slope
Figure 7. Example format of the rock fall database narrative document. The narratives are accompanied by only the key information from the organizational categories included in the database.
ID Number Location information Failure type Season Date (mo/day/yr) Relative size

2009071801 Half Dome Porcelain Wall RF Summer 7/18/2009 medium According to Park Geologist Greg Stock: Witnesses on the road to Mirror Lake reported a rock fall from within a steep gully east of the Porcelain Wall and west of Half Dome, at or near the bat-shaped rock fall scar left by earlier rock fall events. This rock fall produced a substantial dust cloud which was captured on video by park visitors. The weather was clear, sunny, and very warm ( 100 degrees Fahrenheit). Thermal stress was a possible trigger. After the event an approximately $5 \mathrm{~m}^{3}$ flake remained hanging above the top of the source area.

2009072001 El Capitan Manure Pile Buttress RF Summer 7/20/2009 very small According to Park Geologist Greg Stock: A small rock fall was reported from Manure Pile Buttress. The weather was sunny, clear, and hot. The trigger may have been related to thermal stress.

2009072002 Glacier Point n/a RF Summer 7/20/2009 very small According to Park Geologist Greg Stock: Rock fall sounds were reported from Glacier Point, but the exact source area could be identified in the dark. The weather was clear and hot, with no recent precipitation; the triggering mechanism was possibly thermal stress.

2009072301 Half Dome Porcelain Wall RF Summer 7/23/2009 small According to Park Geologist Greg Stock: Stock heard a rock fall at approximately 02:00 from Yosemite Village, emanating from Tenaya Canyon. Investigation by him later that morning showed the approximately $5 \mathrm{~m}^{3}$ flake hanging above the 18 July 2009 Porcelain Wall rock fall [see ID 2009071801] source area was missing from the wall.

2009080601 Crocker Point Old Inspiration Point RS Summer 8/6/2009 medium According to Floyd Hayes (written commun., 31 January 2010): Hayes witnessed a rock slide from the Discovery View lookout on the east side of the Wawona Road tunnel. A photograph of the dust cloud and runout path shows the point of origin was near the rim of the south wall of the valley within a steep gully immediately east of Old Inspiration Point. Impact of rock debris at the base of the cliff produced a sizable dust cloud. The rock fall volume was unknown, but is estimated from the photograph to be approximately $100 \mathrm{~m}^{3}$. The photograph shows sunny, dry weather; no trigger was recognized. 
movement events included in this inventory. We thank Butch Farabee, Jr., for providing new information on fatal incidents involving rock falls. Robert Sas, Jr., and Heather Roger helped to compile data for 2006 to 2009, and were supported by the Geological Society of America's GeoCorps America Program. Kenneth Bodhi (USGS) developed macros for transferring the narrative data to the supplemental report format. Chuck Powell (USGS) reviewed the geologic names referenced in the text and database. Finally, Mark Reid (USGS) and Paul Santi (Colorado School of Mines) provided helpful reviews of this report.

\section{References Cited}

Bateman, P.C., 1992, Plutonism in the central part of the Sierra Nevada batholith, California: U.S. Geological Survey Professional Paper 1483, 186 p, http://pubs.er.usgs.gov/ publication/pp1483.

Brunnetti, M.T., Guzzetti, F., and Rossi, M., 2009, Probability distribution of landslide volumes: Nonlinear Processes in Geophysics, v. 16, p. 179-188, doi:10.5194/ npg-16-179-2009.

California Department of Water Resource (CDWR), 2010, California Data Exchange Center: State of California, accessed March 14, 2013, at http://cdec.water.ca.gov/ queryCSV.html.

Calkins, F.C., Huber, N.K., and Roller, J.A., 1985, Bedrock geologic map of Yosemite Valley, Yosemite National Park, California: U.S. Geological Survey Miscellaneous Investigations Series Map I-1639, scale 1:24,000, available at http://pubs.er.usgs.gov/publication/i1639.

Chau, K.T. and Lin, P., 2011, Crack propagations on the rock face at Glacier Point of the Yosemite National Park after the 1999 rockfall, in Bonelli, S., Dascalv, C., and Nicot, F., eds., Proceedings of the 9th International Workshop on Bifurcation and Degradation in Geomaterials: Springer series in Geomechanics and Geoengineering, v. 11, p. 159164, doi:10.1007/978-94-007-1421-2.

Chau, K.T., Wong, R.H.C., Liu, J., and Lee, C.F., 2003, Rockfall hazard analysis for Hong Kong based on rockfall inventory: Rock Mechanics and Rock Engineering, v. 36, p. 383-408, doi:10.1007/s00603-002-0035-z.

Collins, B.D. and Stock, G.M., 2010, Correlation between thermal gradient and flexure-type deformation as a potential trigger for exfoliation-related rock falls [abs.]: Eos (American Geophysical Union Transactions), v. 91, Fall meeting supplement, abs. EP43A-0742.
Dodge, F.C.W., and Calk, L.C., 1987, Geologic map of the Lake Eleanor quadrangle, central Sierra Nevada, California: Geologic Quadrangle Map GQ-1639, scale 1:62,500, http:// pubs.er.usgs.gov/publication/gq1639.

Douma, M., curator, 2008, Daylight saving time: Institute for Dynamic Educational Achievement, Webexhibits, accessed January 21, 2011, at http://www.webexhibits.org/ daylightsaving/.

Dussauge, C., Grasso, J.R., and Helmstetter, A., 2003, Statistical analysis of rockfall volume distributionsimplications for rockfall dynamics: Journal of Geophysical Research, v. 108, no. B6, p. 2286, doi:10.1029/2001JB000650.

Dussauge-Peisser, C., Helmstetter, A., Grasso, J.-R., Hants, D., Desvarreux, P., Jeannin, M., and Giroud, A., 2002, Probabilistic approach to rock fall hazard assessmentpotential of historical data analysis: Natural Hazards and Earth System Sciences, v. 2, p. 15-26, doi:10.5194/nhess-215-2002.

Guzzetti, F., Reichenbach, P., and Wieczorek, G.F., 2003, Rockfall hazard and risk assessment in the Yosemite Valley, California, USA: Natural Hazards and Earth System Sciences, European Geosciences Union, v. 3, p. 491-503, doi:10.5194/nhess-3-491-2003.

Hergarten, S., 2012, Topography-based modeling of large rockfalls and application to hazard assessment: Geophysical Research Letters, v. 39, L13402, doi:10.1029/2012GL052090.

Huber, N.K., 1987, The geologic story of Yosemite National Park: U.S. Geological Survey Bulletin 1595, 64 p., http:// pubs.er.usgs.gov/publication/b1595.

Huber, N.K., Bateman, P.C., and Wahrhaftig, C., 1989, Geologic map of Yosemite National Park and Vicinity, California: U.S. Geological Survey Miscellaneous Investigations Series Map I-1874, scale 1:125,000, http:// pubs.er.usgs.gov/publication/i1874.

Huber, N.K., Phillips, W.M., and Bull, W.B., 2007, The slide, in Huber, N.K., 2007, Geological Ramblings in Yosemite: El Portal, Calif., Yosemite Association, p. 115-121.

Hungr, O., Evans, S.G., and Hazzard, J., 1999, Magnitude and frequency of rock falls and rock slides along the main transportation corridors of southwestern British Columbia: Canadian Geotechnical Journal, v. 36, p. 224-238, doi:10.1139/t98-106.

Keefer, D.K., 1984, Landslides caused by earthquakes: Geological Society of America Bulletin, v. 95, p. 406-421, doi:10.1130/0016-7606(1984). 
Kistler, R.W., 1973, Geologic map of the Hetch Hetchy Reservoir quadrangle, Yosemite National Park, California: Geologic Quadrangle Map GQ-1112, scale 1:62,500, http:// pubs.er.usgs.gov/publication/gq1112.

LeConte, J.N., 1875, A journal of ramblings through the High Sierras of California: San Francisco, Francis and Valentine, $103 \mathrm{p}$.

Luckman, B.H., 1976, Rockfalls and rockfall inventory data: some observations from Surprise Valley, Jasper National Park, Canada: Earth Surface Processes and Landforms, v. 1, p. 287-298, doi:10.1002/esp.3290010309.

Lundquist, J.D., and Cayan, D.R., 2007, Surface temperature patterns in complex terrain-daily variations and longterm change in the central Sierra Nevada, California: Journal of Geophysical Research, v. 112, D11124, doi:10.1029/2006JD007561.

Malamud, B.D., Turcotte, D.L., Guzzetti, F., and Reichenbach, P., 2004, Landslide inventories and their statistical properties: Earth Surface Processes and Landforms, v. 29, p. 68-711, doi:10.1002/esp.1064.

Matsuoka, N., and Sakai, H., 1999, Rockfall activity from an alpine cliff during thawing periods: Geomorphology, v. 28, p. 309-328, doi:10.1016/S0169-555X(98)00116-0.

Matthes, F.E., 1930, Geologic history of the Yosemite Valley: U.S. Geological Survey Professional Paper 160, 137 p., accessed March 19, 2013, at http://www.nps.gov/history/ history/online_books/geology/publications/pp/160/.

Muir, J., 1912, The Yosemite: Century Company, 284 p. (Reprinted 1962, Garden City, New York, Anchor Books, Doubleday \& Company, Inc., 225 p.)

Peck, D.L., 2002, Geologic map of the Yosemite Quadrangle, central Sierra Nevada: U.S. Geological Survey Geologic Investigations Series Map I-2751, 1 sheet, scale 1:62,500, http://pubs.er.usgs.gov/publication/i2751.

Sanderson, F., Bakkehoi, S., Hestnes, E., and Lied, K., 1996, The influence of meteorological factors on the initiation of debris flows, rockfalls, rockslides, and rockmass stability, in Senneset, K., ed., Landslides - proceedings of the VII International Symposium on Landslides, Trondheim, Norway: Rotterdam, A.A. Balkema, v. 1, p. 97-114.

Snyder, J., 1981, The slide and rebuilding of the demolished Yosemite Falls trail: Yosemite, v. 47, no. 12, p. 3-5.

Snyder, J., 1986a, Anatomy of a rockslide: Yosemite, v. 48, no. 3, p. 4-5, 12, http://www.yosemite.ca.us/library/ yosemite/48-3.pdf.

Snyder, J., 1986b, The powerful storms of winter 1986: Yosemite, v. 48, no. 2, p. 6-7, http://www.yosemite.ca.us/ library/yosemite/48-2.pdf.
Snyder, J., 1996, The ground shook and the sky fell: Yosemite, v. 58 , no. 4 , p. $2-9$, http://www.yosemite.ca.us/library/ yosemite/58-4.pdf.

State of California, 1949, Proposed Amendments to Constitution for Special State Election, November 8, 1949, Daylight Saving Time, Prop. 12, Part II, p. 20, accessed April 18, 2013, at http://librarysource.uchastings.edu/ ballot_pdf/1949s.pdf

State of California, 1962, Proposed Amendments to Constitution for Special Election and Primary Election, June 5, 1962, Daylight Saving Time, Prop. 6, Part II, p. 9, accessed April 18, 2013, at http://librarysource.uchastings. edu/ballot_pdf/1962p.pdf.

State of California, 2013, Secretary of State's Office, Elections Initiative History, accessed July 30, 2012 at www.sos. ca.gov/elections/init_history.pdf.

Stock, G.M., and Uhrhammer, R.A., 2010, Catastrophic rock avalanche 3600 years BP from El Capitan, Yosemite Valley, California: Earth Surface Processes and Landforms, v. 35, p. 941-951, doi:10.1002/esp.1982.

Stock, G.M., Bawden, G.W., Green, J.K., Hanson, E., Downing, G., Collins, B.D., Bond, S., and Leslar, M., 2011, High-resolution three-dimensional imaging and analysis of rock falls in Yosemite Valley, California: Geosphere, v. 7, p. 573-581, doi:10.1130/GES00617.1.

Stock, G.M., Martel, S.J., Collins, B.D., and Harp, E.L., 2012, Progressive failure of sheeted rock slopes - the 2009-2010 Rhombus Wall rock falls in Yosemite Valley, California, USA: Earth Surface Processes and Landforms, v. 37, p. 546-561, doi:10.1002.esp.3192.

Tatard, L., Grasso, J.R., Helmstetter, A., and Garambois, S., 2010, Characterization and comparison of landslide triggering in different tectonic and climatic settings: Journal of Geophysical Research, v. 115, F04040, doi:10.1029/2009JF001624.

Uhrhammer, R.A., 1996, Yosemite rock fall of July 10, 1996: Seismological Research Letters, v. 67. p. 47-48, doi:10.1785/gssrl.67.6.47.

U.S. Geological Survey, 2007, Map of Yosemite Valley, Yosemite National Park and Wilderness, California, Mariposa County: U.S. Geological Survey, 1 sheet, scale $1: 24,000$.

U.S. Geological Survey, 2011, National Earthquake Information Center, Global earthquake search (beta), accessed March 19, 2013, at http://earthquake.usgs.gov/ earthquakes/eqarchives/epic/. 
Vargas, E.A., Jr., Velloso, R.Q., Chavez, L.E., Gusmao, L., Amaral, C.P., 2013, On the effect of thermally induced stresses in failures of some rock slopes in Rio de Janeiro, Brazil: Rock Mechanics and Rock Engineering, v. 46, no. 1, p. 123-134, doi:10.1007/s00603-012-0247-9.

Varnes, D.J., 1978, Slope movement types and processes, in Schuster, R.L. and Krizek, R.J. eds., Landslides - analysis and control: Washington, D.C., Transportation Research Board, National Academy of Science, Special Report 176, p. 11-33.

Whitney, J.D., 1868, The Yosemite book-a description of the Yosemite Valley and the adjacent region of the Sierra Nevada, and of the big trees of California, illustrated by maps and photographs: New York, Julius Bien, 116 p., 28 plates, 2 maps (Reprinted 1870, Cambridge, Mass., University Press, 155 p.).

Wieczorek, G.F., 1981, Rock falls in Yosemite Valley from the Mammoth Lakes, California, earthquake sequence of May 25-27, 1980 [abs.]: Geological Society of America Abstracts with Programs, v. 13, n. 2, p. 114.

Wieczorek, G.F., 1996, Landslide triggering mechanisms, in Turner A.K., and Schuster, R.L., eds., Landslidesinvestigation and mitigation: Washington, D.C., Transportation Research Board, National Research Council, National Academy Press, Special Report 247, p. 76-90.

Wieczorek, G.F., 2002, Catastrophic rockfalls and rockslides in the Sierra Nevada, USA, in Evans, S.G., and DeGraff, J.V., eds., Catastrophic landslides - effects, occurrence, and mechanisms: Boulder, Colo., Geological Society of America, Reviews in Engineering Geology, v. XV, p. 165-190.

Wieczorek, G.F., and Jäger, S., 1996, Triggering mechanisms and depositional rates of postglacial slopemovement processes in the Yosemite Valley, California, Geomorphology, v. 15, p. 17-31, doi:10.1016/0169555X(95)00112-I.

Wieczorek, G.F., and Snyder, J.B., 1999, Rock falls from Glacier Point above Camp Curry, Yosemite National Park, California: U.S. Geological Survey Open-File Report 99-385, http://pubs.usgs.gov/of/1999/ofr-99-0385/.

Wieczorek, G.F., and Snyder, J.B., 2004, Historical rock falls in Yosemite National Park, California: U.S. Geological Survey Open-File Report 03-491, http://pubs.usgs.gov/ of/2003/of03-491/.

Wieczorek, G.F., Alger, C.S., and Snyder, J.B., 1989, Rockfalls in Yosemite National Park, California, in Brown, W.M., III, ed., Landslides in central California-San Francisco and central California, July 20-29, 1989, Field trip guidebook: Washington, D.C., American Geophysical Union, Field Trip Guidebook T381, p. 56-62.
Wieczorek, G.F., Snyder, J.B., Alger, C.S., and Isaacson, K.A., 1992, Rock falls in Yosemite Valley, California: U.S. Geological Survey Open-File Report 92-387, 38 p., 4 pls., available at http://pubs.usgs.gov/of/1992/0387.

Wieczorek, G.F., Nishenko, S.P., and Varnes, D.J., 1995, Analysis of rock falls in the Yosemite Valley, California, in Daemen, J.J.K., and Schultz, R.A., eds., Rock mechanics: American Rock Mechanics Association, Proceedings of the 35th U.S. Symposium on Rock Mechanics, June 5-7, 1995, Reno, Nev., p. 85-89.

Wieczorek, G.F., Morrissey, M.M., Iovine, G., and Godt, J., 1998, Rock-fall hazards in the Yosemite Valley: U.S. Geological Survey Open-File Report 98-467, http://pubs. usgs.gov/of/1998/ofr-98-0467/.

Wieczorek, G.F., Morrissey, M.M., Iovine, G., and Godt, J., 1999, Rock-fall potential in the Yosemite Valley, California: U.S. Geological Survey Open-File Report 99-578, http:// pubs.usgs.gov/of/1999/ofr-99-0578/.

Wieczorek, G.F., and Snyder, J.B., 2009, Monitoring slope movements in Young, R., and Norby, L., eds., Geological Monitoring: Geological Society of America, Boulder, Colo., p. 245-271.

Wieczorek, G.F., Snyder, J.B., Waitt, R.B., Morrissey, M.M., Uhrhammer, R., Harp, E.L., Norris, R.D., Bursik, M.I., and Finewood, L.G., 2000, The unusual air blast and dense sandy cloud triggered by the July 10, 1996, rock fall at Happy Isles, Yosemite National Park, California: Geological Society of America Bulletin, v. 112, p. 75-85, doi:10.1130/0016-7606(2000).

Wieczorek, G.F., Stock, G.M., Reichenbach, P., Snyder, J.B., Borchers, J.W., and Godt, J.W., 2008, Investigation and hazard assessment of the 2003 and 2007 Staircase Falls rock falls, Yosemite National Park, California, USA: Natural Hazards and Earth System Sciences, v. 8, p. 421-432, doi:10.5194/nhess-8-421-2008.

Zimmer, V.L., Collins, B.D., Stock, G.M., and Sitar, N., 2012, Rock fall deposition and dynamics - an integrated analysis of the 2009 Ahwiyah Point rock fall: Earth Surface Processes and Landforms, v. 37, p. 680-691, doi:10.1002/ esp.3206.
Menlo Park Publishing Service Center, California Manuscript approved for publication May 1, 2013 Edited by Claire M. Landowski Design and layout by Jeanne S. DiLeo 


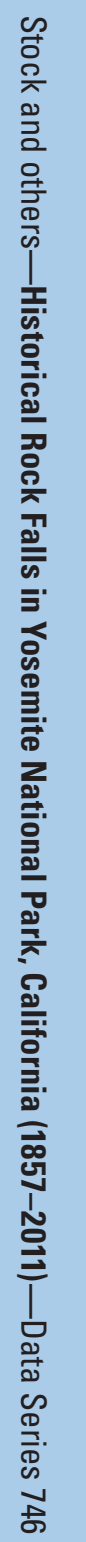

